\title{
İCRA VE İFLÂS HUKUKUNDA ZARAR VERME KASTINDAN DOLAYI İPTAL DAVASI (IIIK M. 280)
}

\author{
Action for Rescission Owing to the Intention to Create Damage in \\ Bankruptcy and Execution Law
}

\section{Levent BÖRÜ}

GİRIŞ § 1. IPTAL DAVASI İLE İLGILİ GENEL OLARAK, A. Amacı ve Hukuki Niteliği, B. Konusu, C. Benzer Davalarla İlişkisi, I. Muvazaa ve İptal Davası Arasındaki İlişki, II. İnançlı İşlem ve İptal Davası Arasındaki İlişki, D. Koşulları, I. Alacaklının Kesin veya Geçici Aciz Belgesine Sahip Olması, II. İptale Tâbi Tasarrufun Davacının Alacağının Doğumundan Sonra Yapılmış Olması, § 2. ZARAR VERME KASTINDAN DOLAYI İPTAL DAVASI, A. İcra ve İflâs Kanunu'nun 280. maddesinin 4949 sayılı Kanunla Değiştirilmeden Önceki Hâli, B. İcra ve İflâs Kanunu'nun 280. maddesinin 4949 sayılı Kanunla Değiştirilmesinden Sonraki Hâli, I. Genel Olarak, II. İptal Davas1 Açılabilmesi İçin Gerekli Unsurlar, 1.Borçlunun Borca Batık Olması, 2.Borçlunun Zarar Verme Kastı İle İşlem Yapması, a. Zarar Verme Kastı Kavramı, b. Zarar Verme Kastının Kanun Tarafindan Varolduğunun

\footnotetext{
* Ankara Üniversitesi Hukuk Fakültesi, Medenî Usûl ve İcra-İflâs Hukuku Anabilim Dalı Araştırma Görevlisi.
} 
Kabul Edildiği Karineler aa. Borçlunun Yakın Hısımları İle Yaptığı İşlemler, bb. Borçlunun Ticari İşletmesini veya İşyerindeki Mallarını Devretmesi, 3. Üçüncü Kişinin İyiniyetli Olmaması, 4. Tasarruf İşleminden İtibaren Beş Yı1 İçinde Borçlu Aleyhine Takip Yapılması, $\S$ 3. ZARAR VERME KASTINDAN DOLAYI AÇILAN IPTAL DAVASININ YARGILAMA USÛLÜ, A. İptal Davasının Konusu, B.İptal Davasının Tarafları, I. Hacizdeki İptal Davası, 1. Davacı, 2. Daval1, II. İflâstaki İptal Davası, 1. Davac1, 2. Daval1, C. Deliller ve Delilerin Takdiri, D. İptal Davası Açma Süresi, §4. İPTAL DAVASININ SONUÇLARI, A.Hacizdeki İptal Davasının Sonuçları, B.İflâstaki İptal Davasının Sonuçları, SONUÇ

\section{ÖZET}

Hacizde borçlunun mallarının haczedilmesinden önce ve iflâsta borçlunun iflâsına karar verilmesinden önce, borçlunun mal ve hakları üzerindeki tasarruf yetkisinde herhangi bir kısitlama yoktur. Bu sebeple, iflâs etmek üzere olan veya yakında mallarına haciz konulması ihtimali bulunan borçluların, mallarını alacaklılardan kaçırmak için, bazı şüpheli tasarruflarda bulunduklarına çok rastlanır. İşte, bir borçlunun, mallarının haczinden veya iflâs etmeden önce, alacaklılarından mal kaçırmak için yapmış olduğu şüpheli tasarrufların iptal ettirilebilmesi için, alacaklılara bir dava açma hakkı tanınmıştır ki, buna iptal davası denir (m.277-284). Biz bu çalışmamızda, m. 280'de düzenlenen, malvarlı̆̆ı borçlarına yetmeyen bir borçlunun, alacaklılarına zarar verme kastıyla yaptı̆̆ 1 tasarrufların iptal edilebilmesi hâlini inceleyeceğiz.

Anahtar Kelimeler: Zarar verme kastından dolayı iptal davası, tasarrufun iptali davası, zarar verme kastı, muvazaalı işlem, borca batıklık

\section{ABSTRACT}

There is no restriction on the power of a debtor to dispose of his assets before the attachment of his goods or adjudication of his bankruptcy. For this reason, it is prevalent that debtors, who totter on the 
verge of bankruptcy or face the danger of attachment, make some doubtful dispositions. To avoid these doubtful dispositions of the debtor, which are made before the attachment or bankruptcy in order to hide assets, there is a right of action for the creditors, called an "action for rescission" (Articles 277-284). In this study, we will analyze the voidability of the debtor's dispositions which are made with the intention of defrauding the creditors, as regulated in Article 280.

Keywords: Action for rescission owing to the intention to damage, action for rescission (action for rescission of disposition), intention to damage, fictitious transaction, excessive indebtedness (doubtful dispositions)

\section{GİRIŞ}

Hacizde borçlunun mallarının haczedilmesinden önce ve iflâsta borçlunun iflâsına karar verilmesinden önce, borçlunun mal ve hakları üzerindeki tasarruf yetkisinde herhangi bir kısıtlama yoktur. Bu sebeple, iflâs etmek üzere olan veya yakında mallarına haciz konulması ihtimali bulunan borçluların, mallarını alacaklılardan kaçırmak için, bazı şüpheli tasarruflarda bulunduklarına çok rastlanır. Örneğin, borçlu mallarını karısına, çocuklarına veya bir arkadaşına satıp devretmiş gibi işlem yapar veya alacaklılarından birini korumak için bazı mallarını, borcuna karşılık olmak üzere o alacaklıya devreder. Bu gibi, şüpheli tasarruflardan sonra, borçlunun alacaklıları, onun mallarını haczettirmek istedikleri zaman hiç mal bulamazlar veya çok az mal bulurlar ve bu sebeple alacaklarını tam olarak alamazlar veya borçlu iflâs edince, borçlunun iflâs masasına çok az bir mal girer ve bu malların bedeli alacaklıların alacağını karşılamaya yetmez. Oysa borçlunun iflâs veya hacizden önce yapmış olduğu şüpheli tasarruflar ile elinden çıkarmış olduğu mallar borçlunun mülkiyetinde olmuş olsa, alacaklılar bunların satılmasından elde edilen para ile tatmin edilecekler veya ellerine daha fazla para geçecektir.

İşte, bir borçlunun, mallarının haczinden veya iflâs etmeden önce, alacaklılarından mal kaçırmak için yapmış olduğu şüpheli tasarrufların iptal ettirilebilmesi için, alacaklılara bir dava açma hakkı tanınmıştır ki; buna iptal davası (Anfechtungsklage) denir (m.277-284). 
İcra ve İflâs Kanunu, borçlunun iptale tâbi tasarruflarını üç grup altında düzenlemektedir (m. 278-280). Biz bu çalışmamızda, m. 280'de düzenlenen, malvarlığı borçlarına yetmeyen bir borçlunun, alacaklılarına zarar verme kastıyla yaptığı tasarrufların iptal edilebilmesi hâlini inceleyeceğiz.

İcra ve İflâs Kanunu m. 280, birkaç kez kanun koyucu tarafından değiştirilmiştir. Zira, 538 sayılı Kanun ile değiştirilmeden önce, m.280'nin kenar başlığ1 "Hile sebebiyle butlan" şeklinde idi ve m. 280'nin konusu olan tasarruflara hileli tasarruflar denilmekte idi. 538 sayılı Kanunla yapılan değişiklik ile, m. 280'nin kapsamı daha da genişletilmişti. Daha sonra 4949 sayılı İcra ve İflâs Kanunu'nda Değişiklik Yapılmasına Dair Kanun, 17.07.2003 tarihinde TBMM'de kabul edilerek 30.07.2003 tarih ve 25184 sayllı Resmi Gazete'de yayınlanmıştır. Zira 4949 sayılı Kanunla, İcra ve İflâs Kanunu'nun yüzden fazla maddesinde değişiklik yapılmıştır. İşte, biz bu çalışmamızda 4949 sayılı Kanun'un m. 66. ile değiştirilen İcra ve İflâs Kanunu'nun m. 280/I. fikrası ile, yine 4949 sayılı Kanun'un m.103 ile mülga m.280/II. fıkrası ile ilgili açıklamalarda bulunarak, m. 280 ile yapılan değişikliğin ve ilganın boyutlarını anlatmaya çalışacağız.

\section{§ 1. İPTAL DAVASI İLE İLGILİ GENEL OLARAK}

\section{A. Amacı ve Hukuki Niteliği}

Haczedilen veya iflâs halinde masaya girerek tasfiyeye konu teşkil edecek olan malvarlığ 1 , borçlunun halihazırdaki malvarlığıdır. Haciz ve iflâstan önce borçlu, mameleki üzerinde tam bir tasarruf yetkisine haizdir. İşte bu nedenle, borçlunun bu tasarruf yetkisine dayanarak yapabileceği işlemlere karşı alacaklıları koruyucu niteliği haiz kurumların düzenlenmesi zorunluluğu doğmuştur ${ }^{1}$. İptal davası, alacaklılar hakkında evvelce doğmuş zararları gidermeyi amaçlar. Diğer bir ifadeyle, iptal davasının amacı, borçlunun hacizden veya iflâstan önce, henüz tasarruf yetkisinin kısıtlanmamış olduğu bir dönemde yapmış olduğu ve aslında

${ }^{1}$ Üstündağ, Saim : İflâs Hukuku (İflâs, Konkordato, İptal Davaları ), 5.B., İstanbul 1998, s. 213; Umar, Bilge: Türk İcra ve İflâs Hukukunda İptal Davaları, İstanbul 1963, s. 1; Kostakoğlu, Cengiz Türk Hukukunda İptal Davaları, AD 1989/6, s. 1037; Güneren, Ali: İcra ve İflâs Hukukunda İstihkak Davaları ile Tasarruf İptal Davaları, Ankara 2004, s. 1013; Ansay, Sabri Şakir : Hukuk İcra ve İflâs Usulleri, 3.B., Ankara 1954, s. 325. 
geçerli olan tasarruflar ile malvarlı̆̆ının dışına çıkarmış bulunduğu mallarını, alacaklılarının cebri icra yetkilerinin çerçevesi içine tekrar sokmaktır². Böylece, iptal davası ile, borçlunun kötüniyetle mamelekinden çıkarttığı mal, alacak ve haklar üzerinde cebri icra mümkün olabilmektedir ${ }^{3}$.

Ancak burada hemen şunu belirtmek isteriz ki, iptal davası ile güdülen amaç, üçüncü kişi ile borçlu arasında yapılan hukuki işlemin maddi (medeni) hukuk anlamında iptali değildir ${ }^{4}$. Zira, tasarrufun maddi hukuk anlamında iptali söz konusu olsaydı, malın tekrar borçlunun mülkiyetine dönmesi gerekirdi. Oysa, burada iptal edilen tasarrufun konusu olan mal, yalnız davacı alacaklı bakımından borçlunun malvarlığına dahil sayılmakta ve alacaklı alacağını aldıktan sonra geriye para artarsa, bu para borçluya değil, lehine tasarruf yapılmış olan üçüncü kişiye verilmektedir". Zira, 4949 sayılı Kanunla m.280'nin daha önce "Diğer butlan halleri" olan madde başlığı "zarar verme kastından dolayı iptal" olarak değiştirilmiş ve madde metninde yer alan "batıl" sözcüğünün yerine de metne, "iptal edilebilir" sözcüğü işlenmiştir.

O halde, iptal davası ${ }^{6}$ genel mahkemelerde açılan bir eda davası niteliğindedir ${ }^{7}$. Zira, iptal davası sonunda üçüncü kişi iptale tâbi

${ }^{2}$ Kuru, Baki /Arslan, Ramazan /Yılmaz, Ejder: İcra ve İflâs Hukuku Ders Kitabı, 22.B.., Ankara 2008 s. 614; Üstündağ- İflâs Hukuku s. 213; Muşul, Timuçin: İcra ve İflâs Hukuku, İstanbul 2005, s. 1169.

${ }^{3}$ Kuru, Baki: İ̀ra ve İflâs Hukuku C. IV, 3.B., İstanbul 1997, s. 3411; Muşul s. 1169; Belgesay, Mustafa Reşit: İflâs Kanunu Şerhi, İkinci Bölüm, İstanbul 1950, s. 154; Ansay s. 325,326.

${ }^{4}$ Üstündağ- İflâs Hukuku 216; Umar- İptal Davası s. 16; Muşul s.1166; “İIK m. 277'de tasarrufun butlanına ve m. 278-280'de batıldır denilmekte ise de, burada söz konusu olan, borçlar hukuku anlamında (BK m. 20) bir butlan değildir. Burada iptal davasına konu yapılan tasarruf başlangıçta (yapıldığında) geçerlidir ve iptal davası kazanılırsa bu tasarruf tamamen iptal edilecek değildir.” (Kuru, Baki: İcra ve İflâs Hukuku El Kitabı, 2.T1pk1 B., Ankara 2006, s. 1196).

${ }^{5}$ Kuru- El Kitabı s. 1196; Umar- İptal Davası s.13; Muşul s. 1209,1210.

${ }^{6}$ İptal davasının hukuki niteliği ile ilgili çeşitli teoriler vardır: 1-) Ayni teoriler: İnşai hak teorisi, butlan teorileri 2-)Borçlar hukuku teorileri: Haksız fiil teorisi, sebepsiz zenginleşme teorisi, kanuni borç teorisi 4-)Sorumluluk hukuku teorileri 5-) Takip hukuku teorileri. Ayrıntılı bilgi için bkz Yıldırım, M. Kamil: İcra ve İflâs Hukukunda İptal Davaları, İstanbul 1995, s. 27-138; Umar-İptal Davası s. 21-34.

7 Üstündağ- İflâs Hukuku s. 217; Pekcanıtez, Hakan/Atalay, Oğuz/ SungurtekinÖzkan, Meral /Özekes, Muhammet: İcra ve İflâs Hukuku, 4.B., Ankara 2006, s. 551; Akkaya, Tolga : "Alacaklıdan Mal Kaçırmaya Yönelik Muvazaalı Tasarrufların İcra ve 
tasarrufun konusunu teşkil eden mallar üzerinde alacaklının cebri icra sahasına tahammül etme yükümü altına girmektedir. Ayrıca iptal davası ayni değil; şahsi bir davadır; zira temelinde alacak hakkı yatmaktadır ${ }^{8}$. Ayrıca, iptal davası ayni bir dava olmadığından, bu dava sonucunda verilen karar, kesinleşmesi beklenmeden uygulanır; çünkü bu dava sonucunda verilen kararlar, Hukuk Usûlü Muhakemeleri Kanunu m. 443/4 kapsamı içine girmez. İptal davası ile, malın mülkiyetinin üçüncü kişiden alınarak, borçluya (ait olduğuna) geri dönmesine karar verilmemekte, sadece alacaklı malın bedelinden alacağını almak yetkisini elde etmektedir?.

\section{B. Konusu}

İptal davasının konusu, alacaklıyı tatmin edecek malvarlı̆g 1 parçalarına doğrudan doğruya ve dolayısıyla etki ederek alacaklının hakkını bu değerler üzerinden almasını engelleyen, alacaklının cebri icrayı yürütme imkanını zorlaştıran ve alacaklının zararına sebep olan, borçlu tarafindan yapılmış tasarruflardır ${ }^{10}$. Tasarruf işlemleri bir hakkı veya hukuki ilişkiyi doğrudan doğruya etkileyen, onu diğer tarafa geçiren, muhtevasını sınırlayan, değiştiren veya ortadan kaldıran hukuki işlemlerdir ${ }^{11}$. Tasarruf işlemi her şeyden önce bir hakkın devri sonucunu

İflâs Kanunu'nda Düzenlenen İptal Davasına Konu Olup Olamayacağı Sorunu", LMUIIIHD 2006/3, s. 668.

8 Pekcanitez/Atalay/Sungurtekin-Özkan/Özekes s. 551; Kurtoğlu, Serda: İcra Hukuku Açısından İptal Davasının Hukuki Niteliği , İBD 1973/7-8, s. 778; Gürdoğan, Burhan: İflâs Hukuku Dersleri (İflâs/Konkordato/İptal Davaları), Ankara 1966, s. 223; Ulukapı, Ömer : İcra ve İflâs Hukuku, Konya 2001, s. 274; Korkusuz, Refik : İcra ve İflâs Hukuku Uygulaması, Ankara 2004s. 312; Muşul s.1168; Umar- İptal Davası s. 19,20; Akyazan, Sitkı: Türk Hukukunda İptal Davas1, AD 1963/3-4, s. 237; Akkaya s. 668; "İptal davası tâli nitelikte bir davadır. Zira alacaklı önce haciz veya iflâs yoluna başvuracaktır. İptal davası ise, bu yolların bir sonuç vermemesi halinde izlenecektir" (Üstündağ- İflâs Hukuku s. 215).

${ }^{9}$ Kuru/Arslan/Yılmaz s. 681; Kurtoğlu s. 777; Umar-İptal Davas1 s. 19,20; Kostakoğlu s. 1038; Süphandağ, Yavuz: İcra ve İflâs Hukukunda Uygulamalar, 3.B., Ankara 2006, s. 558

${ }^{10}$ Umar- İptal Davası s. 55; Muşul s. 1172; Yıldırım-İptal Davası s. 154.

${ }^{11}$ Ayiter, Kudret: Medeni Hukukta Tasarruf Muameleleri, Ankara 1953, s. 13; Eren, Fikret: Borçlar Hukuku Genel Hükümler, 9.B., Ankara 2006, s. 160; Kılıçoğlu, Ahmet: Borçlar Hukuku Genel Hükümler, 7.B., Ankara 2006, s. 32; Bozer, Ali: Borçlar Hukuku Genel Hükümler, Ankara 2002, s. 17; Tunçomağ, Kenan: Borçlar Hukuku, Genel Hükümler, C.I, 4.B., İstanbul 1969, s. 90. 
doğurur. Tasarruf işlemi ile şahsın malvarlığından aktif azalır, diğer tarafta ise çoğalma meydana gelir. Buradaki tasarruftan maksat, borçlunun üçüncü kişilerle veya üçüncü kişiler lehine yapmış olduğu tasarruf işlemleridir. Hemen şunu belirtmek isteriz ki, bu tasarruf işlemlerini en geniş şekilde anlamak gerekir; buradaki tasarruf veya tasarruf işlemi kavramı, hukuki işlem kavramından daha geniştir ${ }^{12}$. Diğer bir ifadeyle, buradaki tasarruf kavramını, doktrindeki görüşe uygun olarak, borçlunun malvarlığını azaltıcı nitelikte bulunan hukuki işlemleri ve hukuki fiillerini ${ }^{13}$ de içerir şekilde en geniş anlamıla kabul etmek gerekir $^{14}$. Zira, kaynak İsviçre Kanunu (SchKG Art.285 vd)'nda ve doktrininde de tasarrufun iptali davasının konusu, borçlu tarafindan yapılan hukuki fiillerdir (Rechtshandlungen) $)^{15}$. Aynı şekilde, Alman Kanunlarında (AnfG § 1,3; InsO § 133) da tasarrufun iptali davasının konusu, borçlu tarafından yapılan hukuki fiillerdir ${ }^{16}$. Örneğin, borçlunun

${ }^{12}$ Kuru-İcra IV s. 3410; Umar- İptal Davası s. 54; Yıldırım- İptal Davas1 s. 141.

${ }^{13}$ Hukuk düzeninin kendisine hukuki sonuç bağladığı iradi fiile, geniş anlamda hukuki fiil adı verilir. Hukuki fiil kavramı geniş yorumlanmalı ve bundan bilinçli iradeye dayanan insan davranışı, veya kısaca iradi davranış anlaşılmalıdır. Bu davranış, müspet bir davranış, bir yapma fiili olabileceği gibi menfi bir davranış, bir yapmama fiili de olabilir. Geniş anlamda hukuki fiiller, hukuka aykırı fiiller ve hukuka uygun fiiller olmak üzere ikiye ayrılır. Hukuka aykırı fiillerin hukuki sonuç doğurmasının sebebi, bunların herkese veya sadece belirli kişilere genel ya da özel nitelikte ödevler yükleyen hukuk normlarını ihlâl etmesidir. Hukuka aykırı fiiller de kendi içlerinde haksız fiil ve borca (sözleşmeye) aykırılık olmak üzere ikiye ayrılır. Hukuka uygun fiiller ise, hukuk düzeninin caiz gördüğü, onayladığı ve kendilerine hukuki sonuç bağladığı fiillerdir. Hukuki filler üçe ayrılır. Bunlar, irade açıklamaları, tasavvur (bilgi) açıklamaları ve duygu açıklamalarıdır. İrade açıklamaları da, iradeyi açığa vuran, dış dünyaya bildiren fiiller olup, üç kısma ayrılır. Bunlar, hukuki işlemler, hukuki işlem benzeri fiiller ve maddi fiillerdir Eren s. 149,150; Bozer s. 8.

${ }^{14}$ Umar- İptal Davası $\quad$ s. 54; Uyar, Talih: İcra ve İflâs Hukukunda İptal Davaları, 2.B., Ankara 1992, s. 21; Kuru-İcra IV s. 3410; Güneren, Ali: İcra ve İflâs Hukukunda İstihkak Davaları ile Tasarruf İptal Davaları, Ankara 2004, s. 1017; Kaçak, Nazif: Tasarruf İptal Davaları, Ankara 2006, s. 18; Yıldırım- İptal Davası s. 141.

15 Jaegler, Carl: Bundesgesetz über Schuldbetreibung und Konkurs, 4.Aufl., Zürich 2001, s. 675; Staehelin, Adrian/Bauer, Thomas: Kommentar zum Bundesgesetz Über Schuldbetreibung und Konkurs (SchKG III- Art 221-352), Basel/Genf/München 1998, s. 2658; Walder, Hans Ulrich: Schuldbetreibungs und Konkurs (SchKG), 17. Aufl., Zürich 2007, s. 362-371; Amonn, Kurt/Gasser, Dominik :Grundriss des Schuldbetreibungs- und Konkursrecht, 6.Aufl. Bern 1997, s. 431; Berz, Hans Peter: Der Paulianische Rückerstattungsanspruch, Zürich 1960, s. 40; Brügger, Erwin: SchKG Gerichtspraxis 1946-2005, Zürich 2006, s. 668.

16 Uhlenberg, Wilhelm: Insolvenzordnung Kommentar, 12.Aufl., München 2003, s. 2026; Kırchof, Hans-Peter/Lwowskı,Jürgen/Stürner,Rolf : Münchener Kommentar 
haksız bir ödeme emrine itiraz etmemesi, zamanaşımı def'inde bulunmaması, hiçbir delile dayanmayan haksız bir davayı kabul etmesi ${ }^{17}$, haklı bir davadan feragat, yeminden çekinmesi, hukuki bir fiil sayılır ve iptal davasina konu olabilir. Nitekim, inceleme konumuz olan zarar verme kastından dolayı iptal davasında 4949 say1lı Kanunun m. 66. ile İcra ve İflâs Kanunu'nun m. 280'nin birinci fikrasının değişikliğiyle getirilen düzenlemede, tasarruf sözcüğü yerine "borçlunun alacaklılarına zarar verme kastıyla yaptığı tüm işlemler" ifadesine yer verilmiştir ${ }^{18}$.

Buna karşılık m. 277-284 uyarınca iptal davasının konusunu teşkil eden işlemler, yukarıda da belirttiğimiz üzere, sadece tasarrufi işlemler olup, borçlandırıcı (iltizami-taahhüt) işlemlerin iptali bu hükümlere dayanılarak istenemez ${ }^{19}$. Borçlandırıcı işlem, bir hakkın devrinin daha sonra yapılacağı hususunda taahhüt mahiyetinde olur. Yani, borçlandırıcı işlemler, malvarlığının aktifini veya oradaki herhangi bir hakkı doğrudan doğruya etkilemez; böyle bir hakkı derhal başkasına devretme, sınırlama, değiştirme veya ortadan kaldırma sonucunu doğurmaz. Bu tür işlemler, yalnız borçlanılan edimin konusunu oluşturan hakkı devir, sınırlama, değiştirme ve ortadan kalkma taahhüdünü kapsar ${ }^{20}$. Diğer bir ifadeyle, borçlandırıcı işlemle, mal veya hak borçlunun malvarlığından çıkmış olmaz $^{21}$. Zira, borçlanma işlemi ile, mal borçlunun mülkiyetinden çıkmayacağından, alacaklı o malı haczettirebilir veya borçlunun iflâsı

zur Insolvenzordnung, Band 2 (§§ 203-269), München 2002, s. 558; Häsemeyer, Ludwig: Insolvenzrecht, 4.Aufl., Köln-München 2007, s. 545; Breuer, Wolfgang: Insolvenzrecht, 2.Aufl., München 2003, s. 123; http://www.gesetze-iminternet.de/aktuell.html.

${ }^{17}$ Umar- İptal Davası s. 54 dpn 54; Uyar-İptal Davası s. 22; Güneren s. 1017; Karşı görüşte olan Kuru ve Üstündağ'a göre ise, borçlu ile üçüncü kişi arasında açılan bir davada, taraflar borçlunun alacaklılarına zarar vermek için anlaşmışlar (hile kullanmışlar) ve mahkeme kararı bu hile nedeniyle borçlu aleyhine verilmiş ise, borçlunun alacaklıları, bu mahkeme kararının iptali için İIK m. 277 ve sonraki maddelerine göre iptal davası açamazlar. Alacaklılar, böyle bir mahkeme kararına karşı, ancak yargılamanın iadesi yoluna (HUMK m. 446) başvurabilirler. Bu konu hakkında bkz. Kuru-İcra IV s.

${ }^{18}$ Güneren s. 1017.

${ }^{19}$ Muşul s. 1172; Umar-İptal Davası s. 56; Güneren s. 1017; Uyar-İptal Davas1 s. 29.

${ }^{20}$ Eren s. 158; Kılıçoğlu s. 32; Bozer s. 17; Tunçomağ s. 89,91.

${ }^{21}$ Ayiter s. 79; Eren s.158; Kılıçoğlu s. 32. 
halinde o mal masaya girer. Bu sebeple borçlandırıcı işlemlerin iptalini istemekte hukuki yarar yoktur ${ }^{22}$.

İcra ve İflâs Kanunu, borçlunun iptale tasarruflarını üç grup altında düzenlemektedir (m.278-280). Bu maddelerde, iptal edilebilecek bütün tasarruflar sayılmış değildir. Kanun bazı iptale tâbi tasarrufları saymış ise de, bu sayma tahdidi olmayıp, her grup tasarruf için genel bir tanımlama yapılarak, hangi tasarrufların iptale tâbi bulunduğu olaya, zamana ve şartlara göre hakimin takdirine bırakılmıştır ${ }^{23}$. Aşağıda, inceleme konumuz olan iptale tâbi tasarruflardan zarar verme kastından dolayı iptal davası ayrıntılı bir şekilde incelenecektir.

\section{Benzer Davalarla İlişkisi}

\section{Muvazaa ve İptal Davası Arasındaki İlişki}

Muvazaa, tarafların, yaptıkları akdin hiç hüküm doğurmaması veya görünüşteki akitten başka bir akdin hükümlerini doğurması konusunda anlaşmaları olarak tanımlanmaktadır. Muvazaada, taraflar, gerçekte yaptıkları akdin hiçbir sonuç doğurmamasını veya başka bir akdin hükümlerini meydana getirmesini istemekte ve bu konuda anlaşmaktadırlar ${ }^{24}$.

${ }^{22}$ Kuru-İcra IV s. 3411; Umar- İptal Davası s. 56; Berkin, Necmeddin: İflâs Hukuku, 4.B., İstanbul 1972, s. 491; Ansay s. 325; Gürdoğan, Burhan: İflâs Hukuku Dersleri (İflâs/Konkordato/İptal Davaları), Ankara 1966, s. 222; Gürdoğan, Burhan: İptal Davaları (İcra ve İflâs Kanunu Değişiklik Tasarısı Hakkında Seminere Sunulan Bildiri, Ankara 1963, s. 157; Yıldırım- İptal Davası s. 143.

${ }^{23}$ Kuru-İcra IV s. 3410; Olgaç, Senai: Yargıtay İçtihatlarının Işı̆̆ı Altında İcra ve İflâs Hukukunda İptal Davaları, Recai Seçkin'e Armağan, Ankara 1974, s. 473; Akşener, Haşmet Sırrı: İcra ve İflâs Hukukunda Tasarrufun İptali Davaları, İstanbul 2002, s. 96; “....iptal davasına konu olabilecek ve neticede iptal edilebilecek tasarruflar İcra ve İflas Kanununda üç grup halinde 278,279,280. maddelerinde öngörülmüştür. $\mathrm{Bu}$ maddelerde iptal edilebilecek bütün tasarruflar tahdidi olarak sayılmış değildir. Kanun iptale tabi tasarruflar için genel bir tanımlama yaparak hangi tasarrufların iptale tâbi olduğu hususunun tayinini hakimin takdirine bırakmıştır. Dava dilekçesinde İcra ve İflas Kanunun 278,279 ve 280 .maddelerinden hangisine istinaden iptal istendiğinin belirtilmesi zorunlu değildir. Hatta bu maddelerden biri gösterilmiș olsa bile mahkeme bununla bağlı olmayıp, diğer maddelerden birine dayanarak iptal kararı verilebilir" HGK 25.11.1987, E:1987/15-381, K: 873 (IKKID 1988/322 s. 5874-5876).

${ }^{24}$ Esener, Turhan: Türk Hususi Hukukunda Muvazaalı Muameleler, Ankara 1956, s. 7; Eren s. 315; Özmen, İhsan/Özkaya,Eraslan: Muvazaa Davaları, Ankara 1993, s. 3; Bozer s. 53; Önen, Turgut: Borçlar Hukuku, Genel Hükümler, Ankara 1999, s. 48; Tunçomağ s. 194; Von Tuhr, Andreas (çev: Cevat Edege) Borçlar Hukukunun 
Muvazaalı işlemlerin iptal davasına konu olup olamayacağı konusunda doktrinde iki görüş ileri sürülmüştür. Bir görüşe göre, muvazaalı işlemler hakkında iptal davası açılamaz ${ }^{25}$. Çünkü muvazaalı tasarruflar hiçbir hüküm doğurmadıkları gibi, bu işleme konu olan mal ve alacaklar borçlunun malvarlığı dışına çıkmazlar. Buna karşılık, iptale tâbi tasarruflar borçlunun hukuken geçerli olan tasarruflarıdır. Bu tasarruf ile mal ve hak borçlunun malvarlığının dışına çıkmış ve üçüncü kişinin malvarlığına geçmiştir. İptal davası ile o mal veya hakkın tekrar borçlunun malvarlığına geçmesi istenemez. Davacı alacaklı veya iflâs masası o mal veya hak üzerinden adeta o mal veya hak henüz borçlunun malvarlığındaymış gibi sadece cebri icra yoluyla hakkını alma yetkisini elde eder (m. 283/I).

Diğer bir görüşe göre ${ }^{26}$ ise, borçlunun tasarruflarının muvazaalı olduğunu öğrenen alacaklı, m. 277 vd hükümlerine göre iptal davası veya Borçlar Kanunu m. 18' e göre muvazaalı işlemin hükümsüzlüğünün tespiti için dava açabilmelidir. Zira alacaklının muvazaa nedeniyle iptal davası açamayacağını kabul etmek, teorik esaslara uygun olmakla birlikte, uygulamada ortaya çıkan sorunları çözmemektedir. Özellikle muvazaa nedeniyle butlan davalarında, muvazaa iddiasının ispatı konusundaki güçlükler ortaya çıkmaktadır. Muvazaa iddiasının ispatı için

Umumi Kısmı, C.I, İstanbul 1952, s. 272; Oğuzman, M.Kemal/Öz,Turgut: Borçlar Hukuku Genel Hükümler, 4.B., İstanbul 2005, s. 108; Kılıçoğlu s. 115.

${ }^{25}$ Belgesay s. 264; Gürdoğan-İlas Hukuku s. 222; Kuru, Baki: El Kitabı s. 1198; Kuruİcra IV s. 3413; Aslan, Kudret: Hacizde İstihkak Davas1, Ankara 2005, s. 492; Umar s. 17; Kuru/Arslan/Yılmaz s. 616,617; Muşul s. 1174; Üstündağ- İflâs.Hukuku s. 216; Pekcanıtez/Atalay/ Sungurtekin-Özkan/Özekes- İcra s. 552; Ulukapı s. 274; Korkusuz s. 314; Güneren s. 1023; Kaçak , Nazif: Tasarruf İptal Davaları, Ankara 2006, s. 78.

${ }^{26}$ Postacioğlu, E. İlhan: Namı Müstear Meselesi-Vekâlet ve İtimat Mukaveleleri ile Muvazaanın Karşılıklı Münasebetleri, C. XIII, İHFM 1947/3, s. 1029; Esener s. 108; Kostakoğlu s. 1041,1042; Özmen/Özkaya s. 613-624; Özkaya, Eraslan: İnançlı İşlem ve Muvazaa Davaları, 3.B., Ankara 2004, s. 215; Uyar, Talih: İcra ve İflâs Hukukunda "Alacaklılara Zarar Vermek Kasdı İle Yapılan Hileli Tasarruflardan Dolayı İptal”(IIYY m.280), MBD Nisan 1992/41, s. 14 vd; Uyar- İptal Davas1 s. 581-582; Yıldırım- İptal Davası s. 142 vd; Kılıçoğlu s. 118 vd; Ansay s. 306; Özdil, Zekai: Tasarrufun İptalini Gerektiren Hukuksal Nedenler, İzBD 1984/4, s. 444; Ülkü, Murat Fatih: Muvazaa Davaları İle İptal Davası Arasındaki İlişki, MBD 1997/62-63, s. 8286; Yavuz, Nihat: Alacaklılardan Mal Kaçırmaya Yönelik İşlemlerin Hukuken Nitelendirilmesi Sorunu ve $\mathrm{Bu}$ Amaçla Yapılan Muvazaalı İşlemler Hakkındaki Yargitay Uygulamasından Örnekler, YD 1999/3, s. 6-9. 
yazılı delille gerek olmayıp tanık beyanı yeterli ise de, çoğu zaman tanık bulmak mümkün olmadığından alacaklı bu imkândan yararlanamamaktadır. İptal davasında ise alacaklı, borçlunun mal kaçırma amacını ispat etmek için tanık dinletmeden dahi, dava konusu işlemin, kanunun öngördüğü belirli kimseler arasında ve belirli süreler içinde yapılmış olduğunu ispatlayarak tasarrufun iptalini sağlayabilmektedir. Muvazaalı tasarruflar için iptal davası açmak imkânı verilmeyecek olursa, muvazaa iddiasının ispatındaki güçlükler veya imkânsızlık sebebiyle hak sahibi alacaklılar zarara uğrayacaklardır.

Yargıtay, muvazaalı işlemlerin iptal davasına konu olup olamayacağı konusunda farklı kararlar vermiş olsa $\mathrm{da}^{27}$, genel olarak Yargıtay'a göre, takip hukuku alanında borçlunun gerek geçerli hukuken işlemleri, gerekse hukuken geçerli sayılmayan muvazaalı işlemleri için ayrım gözetmeden iptal davasının kurallarının (m.277-284) uygulanması gerektiğidir $^{28}$. Diğer bir ifadeyle, Yargıtay’a göre, muvazaalı işlemler, iptal davasına konu olabilir.

${ }^{27}$ Yargıtay bazı kararlarında muvazaalı işlemlerin iptal davasının değil Borçlar Kanunu m. 18 'in konusu içinde değerlendirilmesi gerektiğini belirtmiştir.“....Yüzeysel bakıldığında, iptal davaları ile muvazaa davaları (BK m. 18) arasında bir benzerlik görülmekte ise de, bu benzerlik her iki davanın güttüğü amaçtan öte gitmemektedir. Ancak üçüncü şahısların muvazaa davası ile İ̈K m. $277 \mathrm{vd}$ onu takip eden maddelerinde düzenlenmiş olan alacaklılara, borçlunun bazı hileli tasarruflarını iptal ettirebilmelerini sağlamak için tanınan iptal davalarını birbirinden ayırmak gerekir." HGK, 3.5. 2000, E:4/823, K:851 (Güneren s. 1025,1026; Kaçak s. 79,80); Aynı yönde kararlar için bkz 15.HD 11.10.1993, E:3423, K:3490 (Kaçak s. 95-97); 4.HD 13.5.2002, E:4635, K:5710 (Güneren s. 1026, 1027); "Yargitay yerinde olarak, bu davaları İIK'nun 277 ve sonraki maddelerine göre açılmış iptal davaları olarak nitelendirmekte (HUMK m.76) ve alacaklıların, bu davaları açabilmek için, borç ödemeden aciz belgesine sahip olması gerektiğine karar vermektedir"(Kuru- El Kitabı s. 1199); Yargıtay'ın bu yönde kararları için bkz 1.HD 28.02.2000, E:1781, K:2086 (Kaçak s. 104,105).

28 “....Davalı alacaklı, birleştirilen her üç davada da bu satışların muvazaalı olduğunu ileri sürüp karşı dava olarak satışların iptalini istemiştir (ïIK m.97/17,m. 277 vd). Bu davada, karşı davanın dahi incelenip bir hüküm kurulması gerekirken, karşı dava hakkında herhangi bir karar verilmemesi usul ve yasaya aykırıdır....."15.HD 14.10.1993, E:3719, K:3999 (YKD 1964/20 s. 9); "Borçlunun malvarlığını alacaklılardan kaçırmak amacıyla yakın akrabasına doğrudan ve dolaylı olarak devretmesi danışıklı (muvazaalı) bir işlem olup, İIK 277 ve sonra gelen maddeleri gereğince tasarrufun iptaline konu olur" 15.HD, 22.1.1987, E:49, K: 96 (Kostakoğlu s. 1041) ; "Denilebilir ki, bu tür dava alacaklı davacıya alacağını tahsil olanağı sağlayan nispi nitelikte bir davadır. Kaldı ki davacının istemindeki açıklamalar da alacağın 
Kanaatimizce, muvazaalı işlemler, takip hukukunda (İ̈K m.280) ve maddi hukukta (BK m.18) olmak üzere, hukuki bakımdan, ayrı ayrı nitelendirilmelidir. IİK m. 280'de "takip hukukuna özgü bir muvazaa davası" söz konusudur. Maddi hukuka (BK m.18) ilişkin muvazaalı işlemin hükümsüzlüğünün tespiti için açılan muvazaa davası ile takip hukukuna ilişkin olan muvazaa davasının amacı, konusu, şartları ve sonuçları birbirinden tamamen farklıdır ${ }^{29}$. Eğer bir muvazaalı işlemin, gerekli şartlar oluşmuşsa (BK m.18-İIK m. 288), hem maddi hukuka ilişkin hükümsüzlüğünün tespiti hem de takip hukukuna ilişkin iptali söz konusu olabilmelidir. Örneğin, borçlunun, borcunu ödememek, alacaklılarından mal kaçırmak için taşınır bir malını veya taşınmazını anlaştı̆̆ bir üçüncü kişiye devretmiş olması muvazaalı bir işlemdir. $\mathrm{Bu}$ muvazaalı işlem BK m. 18' e göre hükümsüzdür. Ancak IİK m.288'deki

tahsilini sağlamaya yönelik bulunmaktadır. ....en önemlisi davanın muvazaaya dayanan niteliği gözden kaçırılmadığında, davalı borçlu ile diğer davalı arasında satış işleminin hükümsüzlüğü ile borçlu üzerindeki kaydın düzeltilmesine yer olmadan, davacının alacağını tahsil edilmesini sağlar şekilde dava konusu taşınmazların haciz ve satışını isteme yetkisi davacıya tanınarak uyuşmazlığın çözümlenmesi ve hüküm kurulması gerekir." HGK, 03.05.2000, E. 2000/4-823, K. 2000/851 (YHIMD C. XX S. 230/01, s. 125-128); 1.HD 21.11.1978, E: 10321, K:11567 (YKD 1979/5, s. 616-619); HGK 30.03.1977, E:3265, K:320 (YKD 1978/4, s. 501); 15.HD 26.4. 1984, E:775, K:1466; 13.HD 13.2.1978, E:5021, K:535 ; 15.HD 26.4.1984, E:775, K:1466; 15.HD 22.1.1987, E:49, K:96 (Yavuz s. 7-17); 15.HD 24.10.1994, E: 3652, K: 6122 (Uyar, Talih: İcra ve İflâs Kanunu, İIK 277-355, C.VI, İzmir 1999, s. 7898).

29 "Davacı, desteklerinin ....ait aracın çarpması sonucu ölümü nedeniyle, davaya konu edilen aracın, hükmedilecek tazminattan kurtulmak amacıyla, danışıklı olarak diğer davalıya devredildiği iddiası ile eldeki bu davayı açmıştır. Davaçnın bu davadaki amacı, açtığı tazminat davası sonucu kazanacağı alacağını alabilmeye yönelik olarak, danışıklı olduğunu ileri sürdüğü hukuki işlemlerin kendisi yönünden geçersizliğini sağlamaktır. Davacının zararının desteğin ölüm gününde doğduğunun benimsenmesinde zorunluluk vardır. Ölüme yol açan aleyhine davacı doğduğunun benimsenmesinde zorunluluk vardır. Ölüme yol açan aleyhine davacı tarafindan tazminat davası açıldığı dosyadaki bilgilerden anlaşılmaktadır. Yargılama sonunda davaya konu edilen satışın danışıklı olduğunun kanıtlanması halinde davacı, satışa konu edilen maldan da alacağın tahsili için yararlanabileceklerdir. Ancak, davacının bu hakkı ayni değil şahsi sonuç doğuracağından, danışıklı işlemin kanıtlanması durumunda araç sahibi hakkındaki tescilin iptaline değil, İcra ve iflas yasasının 283/1 kıyasen uygulanarak, iptal ve tescile gerek olmaksızın aracın haciz ve satışına karar verilecektir. Bu davada güdülen amaç da bu olduğundan, davacının karşılanması gereken bir alacağı bulunup bulunmadığının belirlenmesi gerekir ve ona göre karar verilmelidir "HKG 4.07.2007, E: 2007/4-450, K: 2007/449 (26.03.2009 www.kazanc1.com). 
şartlar $^{30}$ oluşmuşsa aynı zamanda da takip hukukuna göre iptal edilebilmesi gerekir ${ }^{31}$. Yani, alacaklının burada bir tercih yapması

${ }^{30} \mathrm{Bkz} \S 2, \mathrm{~B}, \mathrm{II}$.

31 "Davalı Pınar vekili , davanın İIY 277-284. maddelerine göre açılmıș tasarrufun iptal niteliğinde olduğundan aciz belgesinin ibrazı gerektiğini, müvekkili ile davalı ..kardeş olmasına rağmen satışın muvazaalı olmadığını, ...borçları nedeniyle dava konusu taşınmazı satmak istediğini, ancak üzerinde A..bankası lehine ...ytl ipotek olduğundan satamadığını, bu nedenle davalı pınarın adına kayıtlı .....parseldeki taşınmazını müvekkili Gökhan'a Gökhan'nın dava konusu taşınmazı ipotek olarak ...sattığını, ...ipotek bedelini bankaya ödediğini, satışın bedelsiz olmadığını belirterek davanın reddini savunmuștur. Davalı..vekili, davanın İiY 277 ve devamı maddeleri gereğince açıldığını, ön koşul olarak borçlu aleyhine icra takibi yapılması ve aciz belgesinin ibrazı gerektiğini, müvekkilinin dava konusu taşınmazda uzun yıllardır anne ve babası ile birlikte oturduklarını, borçlu.. dava konusu taşınmazı üzerindeki ipotek nedeniyle satamayınca ...n adına kayıtlı taşınmazını Gökhan'a, Gökhan'ın da dava konusu taşınmazı kardeşi Pınar'a sattığını, Gökhan'ın Pınar'dan aldığı daireyi daha sonra sattığını, müvekkilinin 13.07.2005 tarihinde 20.000.00 YTL ipoteği bankaya ödendiğini, satışın ivazsız olmadığını, dava konusu taşınmazın da davalı borçlu adına kayıtlı olmasına rağmen babaları tarafından alındığını belirterek davanın reddini savunmuştur. Bir davada taraflarca öne sürülen maddi olguların hukuki değerlendirmesini yapmak, uygulanacak yasa maddelerini bulmak ve uygulamak HUMK'nun 76. maddesi gereğince hakimin doğrudan görevidir. Dava dilekçesindeki ileri sürülüşe ve yargılama aşamasındaki sözlü ve yazılı açıklamalara göre dava, niteliği itibariyle BK'nın 18. maddesinde tanımını bulan muvazaa hukuksal nedenine dayalı iptal davasıdır. Yüzeysel bakıldığında iptal davaları ile muvazaa davaları arasında bir benzerlik görülmekte ise de, bu benzerlik her iki tür davanın güttüğü amaçtan öte gitmemektedir. İIY'nin 277. maddesinde sözü edilen iptal davaları borçlu tarafından geçerli olarak yapılmış bazı tasarrufların hükümsüz kılınması için açılır. Oysa muvazaa davası, alacaklı ve borçlunun yaptığı tasarrufi işlemin gerçekte hiç yapılmamış olduğunu tespit ettirmeyi amaçlar. Kural olarak, muvazaa nedeniyle hakları ihlal olunan ve zarar gören 3. kişiler (olayımızda davacı) tek taraflı ve çok taraflı hukuki işlemlerinin geçersizliğini ileri sürebilirler, danıșıklı olan bir hukuki ișlem ile 3. kișinin zararlandırılması, ona karşı işlenmiş bir haksız fiil niteliğindedir. Ancak, 3. kişinin danışıklı işlem ile hakkının zarar gördüğünün benimsenebilmesi için onun danışıklı işlemde bulunandan bir alacağının var olması ve bu alacağın ödenmesini önlemek amacıyla danışıklı bir işlemin yapılması gerekir. Somut olayda davalı borçlu Gökhan hakkındaki 2005/103 esas ve 2005/794 esas sayılı icra takipleri kesinleştiğine göre, davacının davalıdan alacaklı olduğu tartışmasızdır. Davacının bu davadaki amacı, alacaklarını tahsil edebilmek için muvazaa nedeniyle temelde geçersiz olan işlemin hükümsüzlügünü sağlamaktır. Esasen muvazaaya dayanan bu gibi davalarda davacının icra takibine geçmesi ve aciz belgesi almasına gerek yoktur. Çünkü az yukarıda açıklandığı gibi İIYY'nın 277 ve izleyen maddelerinde iptal davalarına konu olan tasarruflar özünde geçerli olmalarına rağmen kanunun icra hukuku yönünden iptaline imkan verdiği tasarruflardır. Bu davada ise davacı, muvazaalı işlemle kendisinin zararlandırıldığını ileri sürmektedir. İIY'nin 277 ve izleyen maddelerinde düzenlenen iptal davası açma hakkı davacının genel hükümlere, muvazaaya dayanarak dava açmasına da engel değildir. Davacının iddiasını kanıtlaması durumunda, iddianın 
gerekir. Ancak burada hemen şunu belirtmek isteriz ki, muvazaalı işlemin hükümsüzlüğünün tespiti için bir muvazaa davası açılmış (BK m.18) ve bu dava kesin hükümle sonuçlanmışsa, İIK m. 280'deki iptal davasının açılmasında bir hukuki yarar yoktur.

\section{II. İnançlı İşlem ve İptal Davası Arasındaki İlişki}

Bir hakkı bir şahıstan devren iktisap eden kimsenin (itimat edilen), bu hakkı devredenle aralarında kararlaştırılan amaca göre kullanmayı ve gerektiğinde bu hakkı kendisine devretmiş olana (itimat edene) veya bir üçüncü şahsa devretmeyi taahhüt etmesi ve itimat edenin de bu taahhüde güvenerek hakkı devretmiş olması halinde inançlı işlemden bahsedilir ${ }^{32}$. İnançlı işlem genellikle mülkiyet ve alacağın teminat ve tahsil amaciyla üçüncü kişiye devredilmesi şeklinde gerçekleşir. İnançlı işlemde itimat edilen, kendisine devredilen taşınır ve taşınmaz malın tam maliki ya da alacağın tam sahibi olur. İnançlı işlemle gerçekleşen devir geçerlidir ve burada kural olarak bir muvazaadan söz edilemez. Ancak, inançlı işlem alacaklılardan mal kaçırmak amacıyla yapılıyorsa, tarafların iradesi mülkiyetin gerçekten geçmesi yönünde olmadığından muvazaa söz konusu olur ${ }^{33}$.

İnançlı işlem yukarıda yaptı̆̆ımız açıklamalarda belirttiğimiz üzere geçerli bir hukuki işlem olarak hüküm ve sonuç doğurur. Başka bir deyişle, inançlı işleme dayanarak yapılan tasarruf geçerli kabul edilir ${ }^{34}$. Dolayısıyla, doktrinde ${ }^{35}$, koşulların var olması halinde inançlı işlemlere karşı iptal davası açılabileceği konusunda tereddüt edilmemesi gerektiği

taşınmazın aynına ilişkin olmadığı, alacağın tahsiline yönelik bulunduğu da gözetilerek İIK'nın 283/1. maddesi benzetme yoluyla ( k1yasen ) uygulanarak iptal ve tescile gerek olmaksızın davacının taşınmazın haczin ve satışın istenebilmesi yönünden hüküm kurulması gerekecektir. Açıklanan bu maddi ve hukuksal olgulara göre, davanın İIY'nin 277 ve devamı maddelerine dayalı tasarrufun iptali istemine ilişkin olduğu yolundaki mahkemenin kabulüne katılma olanağı yoktur. $\mathrm{O}$ halde mahkemece, danışıklı işlemin var olup olmadı $\breve{g} 1$ konusunda toplanan ve toplanacak taraf delilleri değerlendirildikten ve davalı Pınarın taraf ehliyeti konusunda da gerekli araştırma yapıldıktan sonra sonucuna göre bir karar verilmesi gerekirken, yazılı gerekçelerle davanın reddine karar verilmiş olması isabetsizdir" 17.HD 8.10.2007 E:2007/4397, K:2007/3011 (26.03.2009 www.kazanci.com).

32 Esener s. 146; Eren s. 329,330; Özmen/Özkaya s. 439; Tunçomağ s. 194.

${ }^{33}$ Esener s. 108; Eren s. 332,333; Oğuzman/Öz s. 108-112.

${ }^{34}$ Eren s. 333; Oğuzman/ Öz s.112.

${ }^{35}$ Umar- İptal Davası s. 55; Akkaya s. 668; Özmen/Özkaya s. 621,622. 
belirtilmiştir. Zira, iptal davasının konusu, borçlunun, alacaklıya zarar veren geçerli hukuki tasarruflarıdır.

v. Tuhr'a göre, alacaklılardan mal kaçırmak amacıyla yapılan işlemler ne muvazaa nedeniyle; ne de Borçlar Kanunu m. 20 gereğince hükümsüzdürler. Zira kanun, mal kaçırmak suretiyle alacaklılara zarar verilmesini, ahlak ve adaba aykırı saymamış; sadece bu tip devirleri bazı özel hükümlere tâbi k1lmakla yetinmiştir ${ }^{36}$.

Yargıtay, bazı kararında, mal kaçırmaya yönelik tasarrufların muvazaalı olarak nitelendirilemeyeceğini, bu işlemlerin inançlı işlem olarak kabulü gerektiğini, bu sebeple uyuşmazlığa m. 277-284'de düzenlenen iptal davası hükümlerinin uygulanacağını belirtmiştir ${ }^{37}$.

\section{Koşulları}

\section{Alacaklının Kesin veya Geçici Aciz Belgesine Sahip Olması}

İptal davası açılabilmesi için bir alacaklının zarara uğramış olması gerekir. Zarara uğrama durumu ise, ancak geçici veya kesin aciz belgesi ile belgelendirilebilir (m. 277/b1). Diğer bir ifade ile iptal davası açabilmek hakk1, genel haciz yolu ile takip sonunda kesin (m. 105/I, 143), veya geçici aciz belgesini ${ }^{38}$ (m.105/II) elde etmiş alacaklıya aittir ${ }^{39}$. Aciz

\footnotetext{
${ }^{36}$ v. Tuhr s. 248 vd dpn. 46.

${ }^{37}$ HGK 14.04.2004, E: 2004/15-182, K: 2004/220 (İKID 2004/44, s. 528, s. 3026-3028; YKD 2004/3, s. 1345-1348); Ayn1 yönde bkz 4.HD 30.5.1977, E:11500, K:3670 (YKD 1978 /8, s. 1284-1286); "Ancak belirtelim ki Hukuk Genel Kurulu'nun (14.04.2004, E: 2004/15-182, K: 2004/220), borçlunun somut olaydaki işlemini, mal kaçırmaya yönelik işlemlerin kanun koyucu tarafından BK m. 20 anlamında hükümsüz kabul edilmediği, bu tür işlemlerin sadece ahlâk ve adaba aykırı olarak değerlendirilmesine katılmıyoruz"(Akkaya s. 668).

${ }^{38}$ Haciz tutanağında borçlunun haczedilen mallarından başka mallarının bulunmadığı yazılı değilse veya borçlunun haczedilen mallarının takdir edilen kıymetine göre takip konusu alacağa yeteceği anlaşılmakta ise, böyle bir haciz tutanağı geçici aciz belgesi niteliğinde değildir ve alacaklı, böyle bir haciz tutanağı ile iptal davası açamaz"(KuruEl Kitab1 s. 1212).

39 Alacaklının elinde geçici aciz vesikası mevcut ise, buna dayanarak iptal davası açtığında acaba, bu davanın kabulü için, alacaklının hükümden önce bir kesin aciz belgesi getirmiş olmak zorunluluğu var mıdır? Bu konu hakkındaki görüşler için bkz Yıldırım- İptal Davası s. 241-245; "Alacaklının tasarrufun iptali davası açabilmesi için elinde kesin veya geçici aciz belgesi bulunması gerekir. Bu husus iptal davasının açılması için bir ön koşul ise de bunun davanın açılmasından önce alınması zorunlu değildir. Davanın açılmasından sonra bile alınıp ibrazı mümkündür. Davanın
} 
belgesi, iptal davası için özel bir dava şartıdır. Mahkemenin, davacı alacaklının aciz belgesine sahip olup olmadığını kendiliğinden araştırması gerekir $^{40}$. Alacaklının, birden fazla icra takibi varsa, her icra takibi için ayrı aciz belgesi alması ve bu aciz belgeleri ile iptal davası açması gerekir. Bir icra takibinde alınan aciz belgesi ile aciz belgesi alınmamış diğer icra takibi konusu alacak için iptal davası açılamaz ve mahkeme, aciz belgesi alınmamış olan icra konusu alacak için de iptal kararı veremez ${ }^{41}$. Haciz tutanağında borçlunun haczedilebilen mallarından başka mallarının bulunmadığı yazılı değilse veya borçlunun haczedilen mallarının takdir edilen kıymetine göre takip konusu alacağa yeteceği anlaşılmakta ise, böyle bir haciz tutanağı ile iptal davası açılamaz ${ }^{42}$.

açılmasından sonra alınabileceği gibi temyiz aşamasında ve hatta bozmadan sonra bile alınıp ibrazı mümkündür " 15.HD 16.04.2007, E:2006/4594, K:2007/2474 (26.03.2009.www.kazanc1 .com).

40 Akşener, Haşmet Sırrı: Tasarrufun İptali Davalarında Aciz Belgesi, LHD 2003/1, s. 51; "Borç ödemeden aciz belgesi almadan iptal davası açmış olan alacaklı, sonradan aldığı aciz belgesini mahkemeye verirse, bununla başlangıçtaki dava şartı noksanlığ 1 ortadan kalkmış, dava şartı tamamlanmış olacağından, mahkemenin iptal davasını esastan incelemesi gerekir. Çünkü, hüküm anında dava şartı tamamdır"(Kuru-El Kitabı s. 1212); Aynı görüşte olanlar için bkz Yıldırım-İptal Davası s. 252; Kostakoğlu s. 14; Uyar-İptal Davası s. 214; Öztek, Selçuk: İcra ve İflâs Hukukunda Borç Ödemeden Aciz Vesikası, İstanbul 1994, s. 68, dpn 48; Ayrıca bkz 15.HD 19.2.2003, E: 4531, K:743 (Güneren s. 1083); 15.HD 2.05.2005, E:2004/7075, K:2005/2686 (Süphandağ s. 561); 19.9.1984, 3110-2637 (YKD 1985/3, s. 400,401); 15.HD 06/03/2007, E:2006/7568, K:2007/1385 (26.03.2009 www.hukukturk.com); "Somut olayda aciz belgesi olmadan iptal davası açılmış olan alacaklıya aciz belgesini ibraz etmesi için...günlü duruşmada 10 günlük kesin süre verilmiş, verilen sürede aciz belgesi ibraz edilmediği için dava ön şart yokluğundan reddedilmiştir. Ancak aciz vesikasının davanın açılmasından önce alınması zorunlu değildir. Aciz vesikası davadan önce yapılan takibe dayalı olarak davanın açılmasından sonra alınabilir. Temyiz aşamasında ve hatta bozmadan sonra dahi alınarak ibrazı mümkündür. Dosya içeriğinden borçlunun mal beyanı dilekçesi ...tarihli haciz tutanaklarının İ̈K'nun 105 madde kapsamında geçici aciz belgesi niteliğinde olduğunun kabulü ile işin esasına girilerek tüm deliller toplandıktan sonra karar verilmesi gerekirken yazılı şekilde hüküm tesisi doğru görülmemiştir" 17.HD 12.05.2008, E:2008/1239, K: 2008/2496 (26.03.2009 www.hukukturk.com); Karşı görüşte olanlar için bkz Berkin s. 498; Umar-İptal Davas1 s. 37; Akyazan s. 236.

${ }^{41}$ Kuru-El Kitabi s. 1211; Muşul 1187-1193.

${ }^{42}$ Kuru-El Kitab1 s. 1212; Akşener-Aciz Belgesi s. 52; Muşul s. 1180,1181;"Borçlunun hiçbir malının bulunmadığını veya ihtiyaden haczedilen mallarının takip konusu alacağa yetmeyeceğini tespit eden ihtiyati haciz tutanağ 1 yalnız başına kesin veya geçici aciz belgesi niteliğinde değildir. Çünkü, alacaklı yedi gün içinde takip yapmaz veya dava açmaz ise ihtiyati haciz hükümsüz kalır. $\mathrm{Bu}$ nedenle, alacaklı, ihtiyati haciz tutanağı ile, iptal davası açamaz"(Kuru-El Kitabı s. 1212). 
Borçlunun iflâsı halinde ise, iflâs alacaklıları aciz belgesine sahip olsalar bile iptal davası açmak hakkı kural olarak iflâs idaresine aittir (m. $187)^{43}$.

Burada dikkat edilmesi gereken bir diğer husus da, iptal davasına bakan mahkemenin, davacının alacağının mevcut olup olmadığını kural olarak inceleyememesidir. Zira aciz belgesi, alacaklının alacaklı olduğunu sadece icra takibi bakımından tespit eden bir belgedir. Yani, aciz belgesi, alacaklıyı, sadece ispat yükünden kurtarır. Davacı alacaklı, iptal davasında gerçekten alacaklı olduğunu ispat etmekle yükümlü değildir ${ }^{44}$.

Kendisine karşı icra mahkemesinde istihkak davası açılan davalı alacaklı, bu istihkak davasına karşı açacağ 1 karşılık dava ile, davacı üçüncü kişinin dayandığı tasarrufun iptalini isteyebilir. Bunun için, davalı alacaklının aciz belgesi ibraz etmek zorunluluğu yoktur; yani, alacaklı, aciz belgesi ibrazına mecbur olmaksızın, iptal davasını, istihkak davsına karşı icra mahkemesinde karşılık dava olarak açabilir (m.97/XVII) ${ }^{45}$.

\section{II. İptale Tâbi Tasarrufun Davacının Alacağının Doğumundan Sonra Yapılmış Olması}

Doktindeki baskın görüş olan ve Yargıtay'ın da benimsemiş olduğu görüşe göre, bir tasarrufun m. 278-280. maddelerine göre iptale tâbi olması için, tasarrufun, davacı alacaklının alacağının doğumundan sonra yapılmış olması gerekir ${ }^{46}$. Ancak, Kuru'ya göre, mevcut (doğmuş) bir

${ }^{43}$ Bununla beraber iflâs alacaklıları, iki istisnai halde iptal davası açabileceklerdir bkz $\S$ 3, B, II, 1 .

${ }^{44}$ Kuru- El Kitabi s. 1213.

45 "Davacı, karşı davalı 3. kişi dava konusu 4 adet aracı noter satış senedi ile satın aldığını belirterek, üzerlerine konulan haczin kaldırılmasını istemiştir. Davalı, karşı davacı ise, araç satışının mal kaçırma amacına yönelik olduğunu, satışın iptal edilmesi gerektiğinden bahisle karșı dava olarak tasarrufun iptali davası açmıștır" HGK 30.05.2007, E: 2007/21-295, K: 2007/319 (26.03.2009 www.kazanc1.com).

${ }^{46}$ Muşul s. 1175; Berkin s. 499; Üstündağ- İflâs Hukuku s. 215; Kostakoğlu s. 1053; Kuru- El Kitab1 s. 1199; 18.02.2004, E: 2004/15-18, K: 2004/82 (Süphandağ s. 562); 15.HD, 24 1.1996, E: 1996/7253, K: 326 (Uyar-Şerh s. 8031-8032); 15.HD, 2.5.1997, 1997/1844, K: 1997/2333 (YKD 1997/6, s. 947-948); 15.HD 26.6.2000, E: 2000/2648, K: 2000/342 (YHD 2001/XX, s. 235/06, s. 805);26.6.2000, E: 2000/2392, K: 2000/4660 YHD 2001/XX, s. 235/06, s. 805); Karş1 görüşte yazarlar için bkz UyarZarar Verme s. 18; Üstündağ- İflâs Hukuku s. 215; Kuru, İflâs ve Konkordato 
borcun daha sonra senede bağlanması mümkün olduğundan, alacağın doğduğu tarih tespit edilirken, senet tarihinin değil, gerçek doğuş tarihin tespit edilmesi gerekir ${ }^{47}$.

\section{III. İptali İstenen Tasarrufun, Alacaklıya Zarar Vermiş Olması ve Kanuni Unsurları İçermesi}

Borçlunun ancak, belirli kanuni unsurları ihtiva eden tasarrufları iptale tâbidir; yoksa bütün tasarrufları değil ${ }^{48}$. Ancak burada hemen şunu belirtmek isteriz ki, Kanun'da iptal edilebilecek bütün tasarruflar sayılmış değildir. Kanun bazı iptale tâbi tasarrufları saymış (m.278,279 ve 280), ise de, bu sayma tahdidi olmayıp, her grup tasarruf için genel bir tanımlama yapılarak, hangi tasarrufların iptale tâbi bulunduğu olaya, zamana ve şartlara göre hakimin takdirine bırakılmıştır ${ }^{49}$.

Ayrıca, borçlunun tasarrufu, alacaklının cebri icra vasıtasıyla hakkını alabilme imkânını doğrudan doğruya veya dolayısıyla kaldırmış, zayıflatmış veya zorlaştırmış olmalıdır. Diğer bir ifadeyle, borçlu bu tasarrufuyla, alacaklısına zarar vermiş olmalıdır. Bu tasarrufun iktisadi bir değer taşıması ve borçlunun mamelekine ilişkin olması gerekir. $\mathrm{Bu}$ iptal davasının objektif unsurudur ${ }^{50}$.

\section{§ 2. ZARAR VERME KASTINDAN DOLAYI İPTAL DAVASI}

\section{A. İcra ve İflâs Kanunu'nun 280. maddesinin 4949 sayılı Kanunla Değiştirilmeden Önceki Hâli}

09.06.1932 tarihli ve 2004 sayılı İcra ve İflâs Kanunu'nda köklü değişiklikler yapan 4949 sayılı İcra ve İflâs Kanununda Değişiklik yapılmasina Dair Kanun 17.07.2003 tarihinde TBMM'de kabul edilerek 30.07.2003 tarih ve 25184 sayılı Resmi Gazete'de yayınlanmış

kitabında, davacı alacaklının alacağının doğum tarihi, iptale tâbi tasarruftan sonra olsa bile, alacaklının iptal davası açma hakkı vardır, görüşüne yer vermiștir. Ancak, Kuru daha sonra bu görüşünden dönmüştür bkz Kuru-İcra IV s. 3417,3419; Kuru- El Kitabı s. 1199.

${ }^{47}$ Kuru- El Kitabı s. 1199; Aynı görüşte olan Yargıtay için bkz 15.HD 13.1.2004, E: 6711, K: 72 (Güneren s. 1071- 1072); 15HD 6.5.1997, E: 2191， K: 2432 (IKİD 1997 /443 s. 12981).

${ }^{48}$ Üstündağ- İflâs Hukuku s. 216.

${ }^{49}$ Kuru-İcra IV s. 3410; Olgaç s. 473; Akşener-İptal Davas1 s. 96.

${ }^{50}$ Umar- İptal Davası s. 57; Yıldırım- İptal Davası s. 154; Jaegler s. 675; Berz s.51. 
bulunmaktadır. Biz bu çalışmamızda 4949 sayılı Kanunun 66. maddesi ile değiştirilen İcra ve İflâs Kanunu'nun 280.maddesinin I. fikrası ile, yine Kanunun 103 maddesi ile mülga 280. maddesinin II.fikrası ile ilgili açıklamalarda bulunarak yapılan değişikliğin ve ilganın boyutlarını anlatmaya çalışacağız. 4949 sayılı Kanunla İcra ve İflâs Kanunu'nun 280. maddesinin III. ve IV. fikralarında ise herhangi bir değişiklik yapılmamıştır.

İcra ve İflâs Kanunu'nun 280. maddesinin I.ve II. fikraları 4949 sayılı Kanun ile yapılan değişiklikten önce, madde başlı̆̆ 1 ile şu şekildeydi:

"Diğer Butlan Halleri:

Madde 280- Tediye kabiliyetini kısmen veya tamamen kaybetmiş veya hakkında 178 inci maddenin 2 inci fikrasındaki ${ }^{51}$ şartlar tahakkuk etmiş olan borçlunun, iyi niyetli bir şahıstan veya basiretli bir tacirden beklenilmeyecek tasarruflarla mevcudunu eksilttiği ve üçüncü şahsın bu durumu ve muamelenin mahiyetini bildiği veya bilmesi gerektiği hallerde yapılmış olan tasarrufları batıldır. Şu kadar ki, tasarrufun vukuu tarihinden itibaren alacaklı iki sene içinde borçlu aleyhine haciz veya iflâs takibinde bulunmuş olmalıdır.

Borçlunun birinci fikradaki tasarrufu, alacaklıları 1zrar kasıyla yapması ve bu kasta üçüncü şahsın vukufu halinde, tasarruf tarihi ne olursa olsun batıl sayılır."

Aşağıda İcra ve İflâs Kanunu'nun m. 280'nin 4949 sayılı Kanun ile değiştirilmesinden önceki ve sonraki halleri karşılaştırmalı olarak incelenecektir.

51 “m. 280 I c.1 aslında, m.178 II ye atıfta bulunmuştur, fakat 3494 sayılı Kanunla m. 178 'e yeni II.fikra eklenmesi sebebiyle eski fikra II şimdi fikra III olmuştur" (Yıldırım- İptal Davası s. 170, dpn 52); Uyar- Zarar Verme s. 14 dpn 1. 


\section{B. İcra ve İflâs Kanunu'nun 280. maddesinin 4949 sayılı Kanunla Değiştirilmesinden Sonraki Hâli}

\section{Genel Olarak}

İcra ve İflâs Kanunu'nun m. 280'de düzenlenmiş olan, zarar verme kastından dolayı iptal davası ile ilgili açıklamalarımıza geçmeden önce, maddenin 4949 sayılı Kanun ile değiştirilmesinden sonraki hâlini belirtmekte yarar görmekteyiz.

Buna göre, İcra ve İflâs Kanunu m. 280, 4949 sayılı Kanun ile yapılan değişiklikten sonra, madde başlığ ile şu şekli almıştır:

"Zarar verme kastından dolayı iptal

Madde 280- Malvarlığı borçlarına yetmeyen bir borçlunun, alacaklılarına zarar verme kastıyla yaptığı tüm işlemler, borçlunun içinde bulunduğu malî durumun ve zarar verme kastının, emarelerinin bulunduğu hallerde iptal edilebilir. Şu kadar ki, işlemin gerçekleştiği tarihten itibaren beş y1l içinde borçlu aleyhine haciz $(\mathrm{m} .58,167,168)$ veya iflâs (m.155,167,171) yoluyla takipte bulunulmuş olmalıdır.

Üçüncü şahıs, borçlunun karı veya kocası, usul veya füruu ile üçüncü dereceye kadar (bu derece dahil) kan ve sıhrî hısımları, evlat edineni veya evlâtllğı $(\mathrm{m} .278, \mathrm{II} / 1)$ ise borçlunun birinci fikrada beyan olunan durumunu bildiği farz olunur. Bunun hilâfını üçüncü şahıs, ancak 279 uncu maddenin son fikrasına göre isbat edebilir.

Ticari işletmenin (TTK m.11 vd) veya işyerindeki mevcut ticari emtianın tamamını veya mühim bir kısmını devir veya satın alan yahut bir kısmını iktisapla beraber işyerini sonradan işgal eden şahsın, borçlunun alacaklılarını ızrar kasdını bildiği ve borçlunun da bu hallerde 1zrar kastıyla hareket ettiği kabul olunur. Bu karine, ancak iptal davâsını açan alacaklıya devir, satış veya terk tarihinden en az üç ay evvel keyfiyetin yazılı olarak bildirildiğini veya ticari işletmenin bulunduğu yerde görülebilir levhaları asmakla beraber Ticaret Sicili Gazetesiyle; bu mümkün olmadığ 1 takdirde bütün alacaklıların ıttılaını temin edecek şekilde münasip vasıtalarla ilân olunduğunu ispatla çürütülebilir."

İcra ve İflâs Kanunu m. 280 'de malvarlığ borçlarına yetmeyen bir borçlunun, alacaklılarına zarar verme kastıyla yaptığ 1 işlemlerin iptal 
edilebilmesi düzenlenmiştir. Kaynak İsviçre Kanunu (SchKG) Art. 288 2 , e göre, iptal davasında borçlunun, her türlü hukuki fiili kasten yapması ve üçüncü kişinin de bu kastı bilmesi veya görülebilir durumda olması şarttır ${ }^{53}$. İcra ve İflâs Kanunu m. 280 değişiklikten önce Kaynak İsviçre Kanunun'dan (SchKG Art 288) farklı ve daha karmaşıktı ${ }^{54}$. Ancak 4949 sayılı Kanunun m. 66 ile İcra ve İflâs Kanunu'nun m. 280'nin I. fikrası değiştirildiğinden ve m. 103 ile II.fikrası ilga edildiğinden dolayı, m. 280 ile Kaynak İsviçre Kanun'un m. 288 ile paralel hale getirilmiştir. Nitekim bu durum madde gerekçesinde de belirtilmiştir ${ }^{55}$. Maddenin değişiklikten önce yapısındaki karmaşıklık, doktrinde değişik tasnifler yapılmasına neden olmuştur. Aşağıda m. 280 ile ilgili doktrin tarafindan ileri sürülen siniflandirmalar belirtilecektir:

Kuru’ya göre ${ }^{56}, 4949$ sayılı Kanunla m. 280 değişikliğinden önce veya sonra, maddenin metninde veya kenar başlığında "hileli tasarruflar" deyimine her ne kadar yer verilmemiş ise de, maddenin içeriğinden, bu maddenin konusu tasarrufların borçlunun geniş anlamda hileli tasarrufları olduğu anlaşılması gerektiğini belirtmiştir.

Kuru, değişiklikten önce, m. 280’ e göre iptal için gerekli şartları: Tasarrufun yapıldığı dönem, tasarrufun mahiyeti ve tasarrufun iptal süresi

52 "Anfechtbar sind endlich alle Rechtshandlungen, welche der Schuldner innerhalb der letzten fünf jahre vor der Pfändung oder Konkurseröffnung in der dem andern Teile erkennbaren Absicht vorgenommen hat, seine Gläubiger zu benachteiligen oder einzelne Gläubiger zum Nachteil anderer zu begünstigen” SchKG Art 288 (Walder s. $368)$.

${ }^{53}$ Staehelin/Bauer s. 262, 2664; Jaegler s. 681; Amonn/Gasser s. 431; Gaugler, Hans: Die Paulianische Anfechtung Band- I, Basel 1944 , s. 123 vd.

${ }^{54}$ Yıldırım- İptal Davası s. 161,169.

55 "Uygulamada özellikle ekonomik kriz zamanlarında, borçlarını ödemek için mallarını paraya çevirmek isteyen borçluların çok sayıda olması sebebiyle, malların normal değerlerinden daha aşağı fiyatlarda satıldığı herkesçe bilinen bir gerçektir. Bu gibi durumlarda, iyiniyetli bir şahıstan veya basiretli bir tacirden beklenilmeyecek tasarruflarla mevcudun eksiltilmesi şeklinde ifade edilen ölçütün objektiflikten uzak olması bir çok alıcının mağdur olmasına yol açmaktadır. Kaynak İsviçre Kanununda da ifadesini bulan alacaklılara zarar verme kastı ise, maddenin gerçek amacını daha iyi ifade ettiğinden, 280 inci maddenin birinci fikrası bu amaca uygun olarak yeniden düzenlenmiştir” ( Resmi Gazete 30.7.2003, Sayı 25184 4949, Nolu Kanunun Hükümet Gerekçesi).

${ }^{56}$ Kuru-El Kitabı s. 1205; Kuru-İcra IV s. 3453; Aynı görüşte olanlar için bkz Akşener, Haşmet Sırrı: İIYY'nın 280. Maddesinde 4949 Sayılı Yasa İle Yapılan Değişiklik Üzerine Bir İnceleme, LHD 2003/9, s. 2209; Ulukapı s. 273; Akyazan s. 240. 
olarak üç grupta toplamıştır. Yazar son grup içersinde borçlunun niyetine göre alacaklılarına zarar vermek kastıyla hareket edip etmediği şeklinde bir alt ayırım daha yapmaktadır ${ }^{57}$. Ancak değişiklikten sonra, yazarın, m. 280 için böyle bir ayrım yapmadığını görüyoruz ${ }^{58}$.

Umar $^{59}$, maddede yepyeni esaslara göre düzenlenen iki iptal edilebilirlik hâlinden sözetmektedir: Birincisinde, borçluda aranan sübjektif unsurun değiştirildiğini, iyiniyetli bir kişiden ya da basiretli bir tacirden beklenilmeyecek tasarrufların göz önünde tutulduğunu; bu hâlin zaman yönünden sınırlandığını ve bazı karineler konulduğunu belirtmektedir. İkincisinde ise, işyerinin veya işyerindeki emtianın devralınmasına ilişkin olduğunu; bu hâlde borçluda aranan sübjektif unsurların varlığının asıl sayılmış olduğunu açıklamaktadır.

Berkin ve $\mathrm{Uyar}^{60}$, tasarrufları, borçlunun kötüniyetle (m.280/I) ve alacaklılarına zarar verme kastıyla yaptığı tasarruflar (f.II) olarak sinıflandırmaktadırlar.

Gürdoğan ve Yıldırım ise ${ }^{61}$, tasarrufları, belli bir müddete tâbi tutulan tasarruflar ile müddete tâbi olmaksızın iptal davasına konu olacak tasarruflar şeklinde ayırmaktadır.

Yukarıda da belirttiğimiz üzere, kanaatimizce, İcra ve İflâs Kanunu'nun m. 280'nin 4949 sayılı Kanunla I.fikrasının değiştirilmesinden ve II.fikrasının ilga edilmesinden sonra, maddenin değişik tasniflerinin yapılmasına gerek kalmamıştır. Değişiklikten sonra madde, daha basit hâle getirilerek ve malvarlığ borçlarına yetmeyen her bir borçlunun, alacaklılarına zarar verme kastıyla yaptığı her işlemin iptal edilebilmesi hâlini düzenlemiştir. Kanaatimizce, kanun koyucu tarafından, maddede yapılan bu değişiklik yerinde olmuştur. Zira değişiklikten önce de m. 280 doktrin tarafından eleştirilmekteydi ${ }^{62}$.

\footnotetext{
${ }^{57}$ Kuru-İcra IV s. 3453-3472.

${ }^{58}$ Kuru-El Kitabi s. 1205-1208.

${ }^{59}$ Umar- İptal Davası s. 83.

${ }^{60}$ Berkin s. 510; Uyar-İptal Davas1 s. 111-113; Uyar-Zarar Verme s. 14-23.

${ }^{61}$ Gürdoğan -İflâs Hukuku s. 231-237; Yıldırım- İptal Davası s. 170-176.

62 "Kanaatimizce, m.280, kanun koyucu kavramlara hakim olmaması nedeniyle başarısız bir hükümdür”(Yıldırım s. 170); Aynı görüşte olanlar için bkz Umar- İptal Davası s. 81; Gürdoğan-İflâs Hukuku s. 233.
} 
Aşağıda, m. 280'nin değişiklikten sonraki hâli ayrıntılı olarak incelenecektir:

\section{II. İptal Davası Açılabilmesi İçin Gerekli Unsurlar}

\section{Borçlunun Borca Batık Olması}

Değişiklikten önce, m. 280'nin I.fikrasında, borçlunun tasarrufu yaptığ1 sırada; a- "Ödeme gücünü kısmen ya da tamamen kaybetmiş olmalı", yahut b-“Hakkında İcra ve İflâs Kanunu m. 178/III ${ }^{63}$ deki koşullar gerçekleşmiş olmalı"dır. Bu maddede yer alan borçlunun "ödeme gücünü kısmen ya da tamamen kaybetmiş olması" ile neyin anlatılmak istendiği pek açık değildi.

Üstündağ' a göre ${ }^{64}$, m. 280'deki durumda m. 279'dan farklı olarak, pasifin aktiften fazla olması değil, ödeme aczinin varlığı söz konusudur.

Umar, Gürdoğan, Yıldırım ve Uyar ise ${ }^{65}$, kanun koyucunun burada "borca batıklık", "aciz hâli", ödemelerin durdurulması" olaylarından herhangi birinin ortaya çıkmasını aramıştır.

Konunun daha iyi anlaşılması açısından, aciz hâli, borca batıklık, ödemelerin tatili, ödemelerin kesilmesi hukuki kavramlarını tanımlamamız yararlı olacaktır.

Aciz hâli, borca batıklık, ödemelerin tatili ve ödemelerin kesilmesi kavramları birbirinden farklıdır ${ }^{66}$.

63 "İflâsa tâbi bir borçlu aleyhine alacaklılardan birinin haciz yolu ile takibi neticesinde yapılan haciz $(\mathrm{m} .78 \mathrm{vd})$ borçlunun yarı mevcudunun elinden çıkmasına sebep olup da kalanı muaccel ve vâdesi bir sene içinde hülûl edecek diğer borçlarını ödemeye yetişmiyorsa borçlu derhal aczini bildirerek iflâsını istemeye zorunludur."(m. 178/III); "Borca batık olmanın özel bir türü olan, m. 178/III'deki durumun tespiti için...”(Atalay, Oğuz: Anonim Şirketlerin İflâs1, İzmir 1996, s. 45); Doktrinde, bu maddede ayrıca m. 178/III'ün belirtilmiş olmasının gereksiz olduğu belirtilmiştir (Gürdoğan-İflâs Hukuku s. 232; Umar İptal Davası s. 90).

${ }^{64}$ Üstündă - İflâs Hukuku s. 221.

${ }^{65}$ Umar İptal Davası s. 82; Gürdoğan-İflâs Hukuku s. 232; Yıldırım- İptal Davas1 s. 171; Uyar- Zarar Verme s. 14,15.

66 Türk, Ahmet: Anonim Ortaklıkta Sermaye Kaybı ve Borca Batıklığın Hukuki Sonuçları, Ankara 1999, s. 39 vd; Taşpınar Ayvaz, Sema: İcra ve İflâs Hukukunda Yeniden Yapılandırma, Ankara 2005, s. 298; Yıldırım- İptal Davas1 s. 155; Pekcanıtez/Atalay/Sungurtekin-Özkan/Özkekes-İcra s. 393; Kale, Serdar: Aciz 
Ödemelerin tatili (ödemelerin durdurulması), ödeme güçlüğüne düşülmüş olmasının bir göstergesi olmakla beraber, daha ileri ve sorunlu bir duruma işaret eder. Ödemelerin tatilinde borçlu, muaccel borçlarını ödeyemeyeceği konusunda açık veya zımnî bir irade belirtmektedir. Bu durumdaki borçlu, muaccel borçlarını genel ve sürekli olarak ödeyememektedir ${ }^{67}$.

Ödemelerin kesilmesinde de borçlu, muaccel borçlarını ödeyememekte, ancak bu durum borçlu için geçici veya arızî nedenlerden kaynaklanmaktadır. Ödemelerin yapılmasında ödeme güçlügüne dayanan bir süreklilik yoktur; ancak borçlu geçici ve değişik nedenlere dayanan nakit sıkıntısından dolayı ödemelerini kesmiştir ${ }^{68}$.

Aciz (ödeme güçlüğ̈̈) hâlinde ise borçlu, bir likidite sorunu yaşamakta ve bu durum, onun geçici olmayan, sürekli ve genel olarak ödeme araçlarından yoksunluğuna dayanmaktadır. Aciz hâli doktrinde, borçlunun muaccel borçlarını ödeyebilmek için gerekli ödeme araçlarından geçici olmayan yoksunluk hâli olarak tanımlanmaktadır ${ }^{69}$.

Borca batıklık kavramı, kanunda (m.179; TTK 324) tanımlanmamıştır. Borca batıklık, kişinin malvarlığındaki aktif değerler toplamının, pasif değerler toplamını karşılayamaması durumudur ${ }^{70}$.

Borca batıklık ile aciz hâlinin farklı kavramlar olduğunu yukarıda belirtmiştik ${ }^{71}$. Aciz hâlinde, şirketin malvarlığı durumuna bakılmaksızın,

Hâlindeki Borçlunun Bir veya Birkaç Alacaklısını Kayıran Hukuki Fiilleri Dolayısıyla İptal Davas1, Prof Dr. Ergun Önen'e Armağan, İstanbul 2003, s. 191; Breuer s. $50,54$.

${ }^{67}$ Taşpınar s. 298; Pekcanıtez/Atalay/Sungurtekin-Özkan/Özkekes-İcra s. 388,389.

${ }^{68}$ Pekcanıtez/Atalay/Sungurtekin-Özkan/Özkekes-İcra s. 388,389; Taşpınar s. 298.

69 Pekcantez/Atalay/Sungurtekin-Özkan/Özekes- İcra s. 393; Atalay- Anonim Şirketlerin İflâsı s. 24-28, 33; Atalay, Oğuz: Borca Batıklık ve İflâsın Ertelenmesi, İzmir 2006, s.6,7; Türk s. 39 vd; Taşpınar s. 299; Breuer s. 50.

${ }^{70}$ Umar, Bilge: Aciz Hâli- Borca Batıklık Kavramlarının Farkı ve Bu Yönden Yeni MK. Metninin Düştüğ̈̈ Bir Yanlışlık (MK m. 605 f.II, 618), YÜHFD 2004/1, s. 317; Breuer s.54; Atalay-İflâsın Ertelenmesi s. 6; Atalay- Anonim Şirketlerin İflası s. 47; Türk s.31; Türk hukuk literatüründe borca batıklık terimi yeni kullanılmaya başlanmıştır. $\mathrm{Bu}$ terimin yerine genellikle pasiflerin aktifi aşması borçların mevcudu aşması ifadeleri tercih edilmektedir. Çünkü yasa koyucu da şirketin aktiflerinin şirket alacaklarının alacaklarına karşılamaya yetmemesi (TTK m. 324/II), şirketin borçlarının mevcut alacaklarından fazla olması (İ̈K m. 179), şirket borçlarının şirket mevcudundan fazla olması (TTK m.446/II), mevcudun borca yetişmemesi (TMK m. 574) ifadelerini kullanmıştır” (Türk s. 33). 
şirketin muaccel borçları, ödeme araçlarındaki geçici olmayan yoksunluk sebebiyle karşılanamazken, borca batıklıkta şirketin tüm aktifi (ödeme araçları, alacaklar ve diğer malvarlı̆̆1 unsurları), muaccel olsun olmasın şirketin tüm borçlarını karşılamaya yetmemektedir. Yani malvarlı̆̆ 1 yetersizliği söz konusudur ${ }^{72}$.

Kanaatimizce, değişiklikten önceki m. 280'de, kanun koyucu "borca batıklık”(Überschuldung), "aciz hâli”(Zahlungsunfähigkeit), "ödemelerin durdurulması"(Zahlungseinstellung) olaylarından herhangi birinin ortaya çıkmasını aramıştır. Değişiklikten sonra ise, m. 280'de yalnızca borca batıklık hâli düzenlenmiştir. Ancak burada hemen şunu belirtmek isteriz ki, borca batıklık hâli asla borçlu hakkında aciz belgesi alınması hâli demek olmadığı gibi, borçlunun muaccel borçlarını ödeyememesi veya ödemelerin durdurulması ile de aynı şey değildir; burada aranacak olan sadece, borçlu malvarlığındaki pasiflerin icraya konu teşkil edebilecek aktiflerden üstün olması yani onları aşmasıdır. Pasifler hesaplanırken yalnız dava veya icra yolu ile öne sürülebilecek mutalebe (Anspruch) veren borçlar hesaba katılmalıdır. Aktiflerin hesabında ise yalnız haczedilebilir mallar göz önünde tutulacaktır ${ }^{73}$ Zira, değişiklikten sonra, Kaynak İsviçre Kanunundan farklı olarak $^{74}$, maddede yalnızca

71 “Aktifin yetersizliğini kavramı kapsam itibariyle, nakit darlığını da içine alır. Fakat, her aktifin yetersizliği her zaman bir nakit darlığı anlamına gelmez" (Yıldırım- İptal Davas1 s. 156).

72 Atalay-İflâsın Ertelenmesi s. 7; Atalay- Anonim Sirketlerin İflası s. 47; Pekcanıtez/Atalay/Sungurtekin-Özkan/Özkekes -İcra s. 393, 394.

${ }^{73}$ Umar-İptal Davasi s. 71,72.

74 SchKG Art 288'de açıkça "Malvarlığı borçlarına yetmeyen borçlunun” ibaresi geçmemektedir. Ancak, Kanun (SchKG Art 285-292) genelinde ve Art 279'da aciz hâlinden değil, borca batıklıktan (Überschuldungsanfechtung-Die Überschuldungspauliana) sözetmektedir (Ulrich s. 366,368; Jaeger s. 673; Staehelin/Bauer s. 2654; Amonn/Gasser s. 430; Gaugler s. 113,123); “ IIIK m. 279'a göre, borca batık bir borçlunun yaptığı, o maddede belirtilmiş davranışlar, alacaklıların yahut iflâs idaresinin İIK m. 277'deki iptal davasına hak verir. Ne var ki yasamızın kökeni olan İsviçre Yasasında bu maddenin karşılı̆̆ 1 olan borca batıklık (Überschuldung) durumundan söz edildiği görülmektedir..... m. 279 borcunu ödemeyen bir borçludan söz etmektedir. Öğreti, maddemizdeki deyişin yanlış ve yersiz seçildiğine oybirliği göstermekte ise de, o deyişin nasıl anlaşılması gerektiğinde görüş̧ birliği yoktur. ..Kaynak Yasanın Almanca metni, daha fiilin yapıldığı anda borca batık olan borçludan bahseder ki, doğrusu da budur. Yani bu maddede, borca batık olan...Borçlunun...tasarrufları iptal davasına konu olmaktadır." (Umar-Borca Batıklık s. 318,319); Türk s. 33; Borca batıklık unsurunun bir ölçüde m. 278 ve 280 için de 
"malvarlığı borçlarına yetmeyen" tâbiri kullanılmıştır. Doktrinde de, değişiklikten sonra m. 280'nin borca batıklık hâlini esas aldığ1 görüşü ileri sürülmüştür ${ }^{75}$. Diğer bir ifadeyle, kanun koyucu m. 280'de borçlunun, borca batıklık hâlindeki tasarruflarını iptale tâbi kılmıştır ${ }^{76}$. Diğer bir ifadeyle, kanun koyucu m. 280'de borçlunun, borca batıklık hâlindeki tasarruflarını iptale tâbi kılmıştı ${ }^{77}$. Borca batıklık, tüzel kişiler için şirket bilançosundan tespit edilebilir ${ }^{78}$. Gerçek kişiler için ise, borca batıklığın tespiti kolay olmamaktadır. Hakim gerçek kişilerin borca batık olup olmadığını, borçlunun malvarlığındaki pasiflerin icraya konu teşkil edebilecek aktifleri (haczedilebilir malları) aşıp aşmadığına bakarak, dosyada bulunan belgelerden anlayabilir ${ }^{79}$. Ancak, kanaatimizce, gerçek kişilerin borca batık olup olmadığının tespitinin kolay olmaması nedeniyle, hakim borca batıklık tespiti için bilirkişiden yardım alabilmelidir. Zira, Yargitay bir kararında borca batıklık durumunun varlığını ve mali durumun iyileştirilmesi ümidinin bulunup bulunmadığını özel ve teknik bilgi olarak değerlendirmiştir. Bunun sonucunda da, Yargitay, borca batıklık bildirimi üzerine, borca batıklık durumu ve mali durumun iyileştirilmesinin mümkün olup olmadığ 1

geçerli olduğu yönünde görüşler için bkz Yıldırım-İptal Davası s. 202; Umar-Borca Batıklık s. 319; Umar- İptal Davası s. 71,82; Pekcanıtez/Atalay/SungurtekinÖzkan/Özekes-İcra s. 55, 556; Buna karşın Alman Kanunlarına göre, zarar verme kastıyla iptal davasında (Vorsätzliche Benachteiligung- AnfG § 3; InsO § 133), borçlunun tasarrufunun iptal edilebilmesi için, borçlunun tasarrufu yaptığı sırada aciz hâlinde (Zahlungsunfähigkeit) bulunması gerekir Uhlenberg s. 2027; Kırchof, HansPeter /Lwowskı,Jürgen/Stürner,Rolf, s. 558; http://www.gesetze-iminternet.de/aktuell.html.

${ }^{75}$ Pekcanitez/Atalay/Sungurtekin-Özkan/Özkekes-İcra s 558; Umar- Borca Batıklık s. 319; Güneren s. 1141; "Kanaatimizce, m. 280'de aktifin yetersizliği esas alınmalıdır; daha dar kapsamlı olan aciz hâlini esas almak iptal davasının uygulama alanını daraltacaktır. Bir kanun değişikliği ile ...tediye kabiliyetini kısmen veya tamamen kaybetmiş olma...ibaresini, aktifin yetersizliği şeklinde düzeltmek ve böylece m. 178/III'e atıftan tasarruf etmek mümkündür" (Yıldırım- İptal Davası s. 171).

${ }^{76}$ Pekcanıtez/Atalay/Sungurtekin-Özkan/Özkekes-İcra s 558.

${ }^{77}$ Pekcanıtez/AtalaySungurtekin-Özkan/Özekes-İcra s 558.

${ }^{78}$ Türk s. 41; Atalay-İflâsın Ertelenmesi s. 7; Atalay-Anonim Şirketlerin İflâsı s. 47.

${ }^{79}$ Güneren'e göre, alacaklılardan biri veya birkaçının borçlu hakkında yaptığ sonuçsuz kalması, senetlerinin protesto edilmesi, borçlu hakkında geçici veya kesin aciz belgesi alınmış olması, borçlunun konkordato teklif etmesi gibi durumlar borçlunun malvarlığının borca yetmediğini gösterir (Güneren s. 1141). 
yönünde mutlaka bilirkişi incelemesi yaptırılması gerektiği görüşüne varmıştır ${ }^{80}$.

\section{Borçlunun Zarar Verme Kastı İle İşlem Yapması}

\section{a. Zarar Verme Kastı Kavramı}

Hukuka aykırı sonucun fail tarafindan bilerek istenmesine, kast denir. Kasıtta karar verenin iradesi, hukuka aykırı sonuca yönelmiştir. Burada da korunan hukuki bir değer, istenilerek ihlâl edilmektedir. Bu nedenle kanunun yasakladığ davranış adı verilir ${ }^{81}$. Borçlu isteyerek yaptığ 1 bu tasarrufuyla, alacaklısına zarar vermiş olmalıdır; yani alacaklının tatmin edilme imkânını tamamen veya kısmen ortadan kaldırmış, azaltmış veya güçleştirmiş olmalıdır ${ }^{82}$. Diğer bir ifadeyle, bu tasarrufun iktisadi bir değer taşıması ve borçlunun malvarlığına ilişkin olması gerekiir ${ }^{83}$.

Tasarruf, alacaklıya gerçekten zarar vermiş olmalıdır; zarara sebep olmamış bir tasarrufun iptali istenemez. Borçlunun tasarrufu, alacaklının takip hakkını doğrudan veya dolaylı olarak zorlaştırmış olmalıdır ${ }^{84}$. Örneğin, borçlunun, borcunu ödememek, alacaklılarından mal kaçırmak

\footnotetext{
80، Borca batıklık bildirimi üzerine borca batıklık durumunun ve mali durumunun iyileştirilmesinin mümkün olup olmadığı yönünden bilirkişi incelemesi yapılmalıdır, hakimlik mesleğinin gerektirdiği genel ve hukuki bilgi ile çözümü mümkün olan konularda bilirkişi dinlenemez. Ancak çözümü özel ve teknik bilgiyi gerektiren uyuşmazlıkta mahkemenin, bilirkişinin oy ve görüşünü alması gerekir. Borca batıklık durumunun varlığ ve mali durumunun iyileştirilmesi ümidinin bulunup bulunmadığ 1 özel ve teknik bilgi gerektirdiğinden bu konuda uzman bilirkișinin oy ve görüșü hakimi bağlamaz ise de bu tür hallerde hakimin bilirkişi yerine geçerek olayı çözmesi usûle uygun düşmez. Bilirkişi raporu yeterli değilse, yeniden bilirkişi incelemesi yaptırılmalı veya bilirkişiler açıklık olmayan konularda ek ve tamamlayıcı görüş alınarak uyuşmazlık çözülmelidir"19.HD 10.3.2005, E:1373, K:2443 (YKD 2005/7 s. 10491051.

${ }^{81}$ Eren s. 535; "Bu tariften de anlaşıldığı üzere, kasıt iki unsurdan oluşmaktadır. Bunlar, tasavvur (tasarlama) ve irade (isteme) unsurlarıdır. Tasavvur unsuru, hukuka aykırı sonucun, fail tarafından tasavvur edilmesini, tasarlanmasını, bilinmesini, öngörülmesini ifade eder. İrade ise, bu sonucun fail tarafindan istenmesi, kabul edilmesidir. Böylece kasdda, fail; hem davranışı, hem de hukuka aykırı sonucu istemektir. Hatta hukuka aykırı sonucun mutlaka arzu edilmesi şart değildir. Bunun tasvip ve kabul edilmesi, göze alınması da yeterlidir"(Eren s. 535,536).

82 Yildırım- İptal Davası s. 154; Uyar-Zarar Verme s. 22; Umar-İptal Davas1 s. 57.

${ }^{83}$ Häsemeyer s. 589, 593, 608; Jaeger s. 676, 681.

${ }^{84}$ Umar- İptal Davası s. 57; Yıldırım- İptal Davası s. 154.
} 
için taşınır bir malını veya taşınmazını bir üçüncü kişiye devretmiş olması gibi. Borçlunun, bir üçüncü kişiyle böyle bir tasarruf yaparak bütün alacaklılarına zarar vermesi hâli buraya girdiği gibi, borçlunun alacaklılarından bazıları ile anlaşarak diğer alacaklılara zarar vermek kastı ile yaptığı tasarruflar da buraya dahildir ${ }^{85}$.

Değişiklikten önce, m. 280, borçlunun yaptı̆̆ 1 tasarrufları zarar verme kastı ile yapıp yapmamasına göre farklı hükümlere tâbi tutmaktaydı. Borçlu tasarrufunu zarar verme kastıyla yapmışsa, değişiklikten önceki maddenin II.fikrasına tâbi tutulmaktaydı. Diğer bir ifadeyle ödeme kabiliyetini kısmen veya tamamen kaybetmiş olan borçlunun, iyiniyetli bir kişiden veya basiretli bir tacirden beklenilmeyecek tasarruflarla mevcudunu eksiltmesi, bu tasarrufları alacaklılarına zarar vermek kastıyla yapması ve lehine tasarruf yapılan üçüncü kişinin bu zarar verme kastını bilmesi hâlinde, bu tasarrufları, tarihi ne olursa olsun iptale tâbi kılmaktaydı. Ancak, bu hüküm, m. 284 'deki beş yıllık hak düşürücü süre ile sınırlıydı ${ }^{86}$.

Borçlunun alacaklılarına zarar vermek kastıyla yapmadığ tasarrufları ise m. 280/I' e tâbi tutmaktaydı. Diğer bir ifadeyle, borçlunun alacaklılarına zarar vermek kastıyla yapmadığı veya zarar vermek kastının ispat edilemediği hallerde, tasarrufun iptalinin istenebilmesi için, alacaklının, tasarrufun yapıldığı tarihten itibaren iki yıl içinde borçluya karşı haciz veya iflâs yoluyla takipte bulunmuş olması gerekiyordu.

Değişiklikten sonra ise, m. 280'nin değişiklikten önceki I. ve II.fikralarının birleştirilerek ifade edildiği anlaşılmaktadır. Şöyle ki değiştirilmeden önceki I. fikrada bulunan "iyiniyetli bir şahıstan veya basiretli bir tacirden beklenilmeyecek tasarruflar" unsurunun maddeden

${ }^{85}$ Kuru- El Kitabı s. 1206; Kuru-İcra IV s. 3456; “.....Borçlunun muhasebecisi olan kişinin borçlunun ekonomik durumunu, mal kaçırmak için tasarruf yaptığını bilmesi gerekir..." 15.HD 7.4.2003, E:5761, K: 1777; “ Bankadan, müşterek borçlu ve müteselsil kefil sıfatıyla borçlu ile birlikte kredi alan üçüncü kişi ortak iş ilişkisi içindedir. $\mathrm{Bu}$ nedenle borçlunun mal kaçırma kasdını bildiği kabul edilir." 15.HD 19.12.2002, E:5887, K:6046; "Borçlu tarafından üçüncü kişiye devredilen taşınmazların birinde halen borçlunun oturduğu, diğerinin kirasını borçlunun almakta olduğu saptanmış olduğuna göre devralanın borçluyu yakinen tanıdığı ve mal kaçırma amacını bildiğinin kabulü gerekir” 15.HD 14.11.2002, E:4887, K:5209 (Bu Yargitay Kararları için bkz Güneren s. 1144-1154).

${ }^{86}$ Kuru- İcra IV s. 3468. 
çıkarıldığı görülmektedir. Değişiklikten önceki II.fikranın unsuru olan "alacaklıları 1zrar kastı"(alacaklılara zarar verme kastı) değişiklikten sonra maddenin ana unsuru haline dönüştürülmüş ve sadece bu kasıtla yapılan tasarrufların iptali mümkün hâle gelmiştir. Kanunun gerekçesinde ${ }^{87}$ de ifade edildiği gibi " iyiniyetli bir şahıstan veya basiretli bir tacirden beklenilmeyecek tasarruflarla mevcudun eksiltilmesi" şeklindeki ölçüt objektiflikten uzak ve alacaklının mağduriyetini doğuran bir kavramd. Bu kavramın yerine Kaynak İsviçre Kanunu (SchKG) Art 288'deki gibi "alacaklılara zarar verme kastı" (SchädigungsabsichtBenachteilungsabsicht) şeklindeki unsur kabul edilerek madde bu şekilde düzenlenmiştir ${ }^{88}$.

Bütün bunlarla beraber maddenin daha önce "Diğer butlan halleri” olan madde başlığı da "Zarar verme kastından dolayı iptal" olarak değiştirilmiş ve madde metnine işlenmiştir.

Son olarak burada şu hususu belirtmek gerekir: Borçlu tasarrufu yaptığı anda zarar kastı taşımalıdır; fakat bu davranışın tek amacı alacaklıya zarar vermek olmayabilir; bu, muhtemel menfi sonuçların bilinçli olarak dikkate alınması, gayri muayyen kast (dolaylı kast-dolus eventualis) şeklinde de olabilir ${ }^{89}$. Yani, borçlunun gayri muayyen kast ile yapmış olduğu tasarruflarda da alacaklısına zarar vermiş ise iptale tâbidir.

87 “Uygulamada, özellikle ekonomik kriz zamanlarında, borçlarını ödemek için mallarını paraya çevirmek isteyen borçluların çok sayıda olması sebebiyle, malların normal değerlerinden daha aşağı fiyatlarda satıldığı herkesçe bilinen bir gerçektedir. Bu gibi durumlarda, iyiniyetli bir şahıstan veya basiretli bir tacirden beklenilmeyecek tasarruflarla mevcudun eksiltilmesi şeklinde ifade edilen ölçütün objektiflikten uzak olması birçok alcının mağdur olmasına yol açmaktadır. Kaynak İsviçre Kanununda da ifadesini bulan alacaklılara zarar verme kastı ise, maddenin gerçek amacını daha iyi ifade ettiğinden, 280'inci maddenin birinci fikrası bu amaca uygun olarak yeniden düzenlenmiştir ...” (Resmi Gazete 30.7.2003, Say1 25184, 4949 Nolu Kanun 103. madde, madde gerekçesi ve genel gerekçesi).

88 Jaeger s. 681; Staehelin/Bauer 5 s. 2664; Walder s. 368 Gaugler s. 128; Amonn/Gasser s. 434.

${ }^{89}$ Staehelin/Bauer s. 2663; Amonn/Gasser s. 431; Yıldırım- İptal Davas1 s. 167; Kast doğrudan doğruya kast, dolaylı kast olmak üzere ikiye ayrılır. Doğrudan doğruya kasdda zarar veren, meydana gelen sonucu doğrudan doğruya istemekte, kabul etmektedir. Örneğin failin, hasmını öldürmek suretiyle silahını onun üzerine ateşlemesi halinde doğrudan doğruya kast vardır. Dolaylı kasdda ise zarar veren, meydana gelen sonucu doğrudan doğruya istememekle birlikte, onu göze almakta, kabul etmektedir. Örneğin bir kimse, aslında yalnız hasmının evini yakmak istemekte, ancak bu yangın 


\section{b. Zarar Verme Kastının Kanun Tarafindan Varolduğunun Kabul Edildiği Karineler}

Hukukta karine sözünden, varllğı bilenen olumlu veya olumsuz bir olaydan diğer bir olumlu veya olumsuz bir olayın, bir hukuksal durumun varlığı veya yokluğu sonucunun çıkarılmasına olanak veren bir kural anlaşılır. Karineler, fiili karineler ve kanuni (yasal) karineler olmak üzere ikiye ayrılır. Fiili karineler, tarafların olay iddialarının doğruluğunu veya bir delilin güvenilebilirlik derecesi hakkında, hakimin kanaat edinmesine yarayan, yaşam deneylerinin ortaya koyduğu değer hükümleridir. Bu değer hükümlerinin gerçekte hukukla ilgisi yoktur; fakat bunlar dolaylı olarak ve hakimin delil değerlendirmesindeki serbestliği kuralı sayesinde, hukuk için önem taşırlar, yani hakim tarafından gözönüne alınabilirler ${ }^{90}$. Yasal karineler ise, ispat konusu olan somut vakı dişında varlığı anlaşılabilen başka bir vakıadan hareketle, uygulanacak normun koşul vakıasını karşılayabilecek, ispat konusu somut vakıanın varlığı ya da yokluğu veya bir hakkın ya imkân veren ve böylece ispat konusu somut vakıa hakkındaki belirsizlik hâlinin başka bir vakıa dolayısıyla bertaraf edilmesi sonucunu doğuran olumlu ispat yükü kurallarıdır ${ }^{91}$.

Kanun koyucu, m. 280'de davacı alacaklı (veya iflâs idaresi) lehine iki kanuni karine koymuştur. $\mathrm{Bu}$ karinelerin bu maddeye konuluş gerekçesi ise şudur: Tasarrufun iptal edilebilmesi için, borçlunun alacaklılarına zarar verme kastının, lehine tasarruf yapılan üçüncü kişi tarafindan bilinmesi veya bilinmesini gerektiren açık emarelerin bulunması gerekir (m. 280/I, c. 1). Borçlunun zarar verme kasdını ispat yükü davacı alacaklıya düşer. $\mathrm{Bu}$ ispat yükünün yerine getirilmesi çok güç olduğundan kanun koyucu, davacı alacaklı lehine iki kanuni karine koymuştur. Zira bu karinelerde, yaşam deneyi kurallarına göre borçlunun tasarrufu yaparken alacaklılarına zarar verme kastının bulunduğu kabul edilir. Aşağıda, kanun koyucunun davacı alacaklı (veya iflâs idaresi) lehine koyduğu bu iki kanuni karine incelenecektir:

esnasında onun da ölebileceğini düşünerek evi ateşe vermektedir. İşte burada fail, hasmın yanarak ölmesini doğrudan doğruya istememekle birlikte, böyle bir sonucun gerçekleşme ihtimalini kabul etmekte, onu göze almaktadır”(Eren s. 536).

${ }^{90}$ Umar, Bilge/Yılmaz, Ejder : İsbat Yükü, 2.B., İstanbul 1980, s. 165,166.

${ }^{91}$ Umar/ Yılmaz s. 165,167; Atalay, Oğuz : Medeni Usul Hukukunda Menfi Vakıaların İspat1, İzmir 2001, s. 46. 


\section{aa. Borçlunun Yakın Hısımları İle Yaptığı İşlemler}

İcra ve İflâs Kanunu'nun m. 280/II'de, borçlunun yakın hısımları aleyhine bir karine konulmuştur. Lehine tasarruf yapılan üçüncü kişi, borçlunun karısı veya kocası, üst soyu veya alt soyu ile üçüncü dereceye kadar (bu derece dahil) kan, veya kayın hısmı, evlât edineni veya evlâtlı̆g 1 ise, borçlunun birinci fikradaki durumunu, yani borçlunun alacaklılarına zarar verme kastını bildiği farz olunur ${ }^{92}$. Üçüncü kişi, bu karinenin aksini, yani alacaklılarına zarar verme kastını bilmediğini ve bu tasarruflardan yararlanan kimsenin, borçlunun hal ve vaziyetini bilmediğini ispat ederse, yapılan tasarrufun iptal edilmesini engelleyebilir (m. 280/II, son cümle; 279/son fikra).

\section{bb. Borçlunun Ticari İşletmesini veya İşyerindeki Mallarını Devretmesi}

Borçlunun ticari işletmesinin (TTK m.11 vd) veya işyerindeki mevcut ticari mallarının tamamını veya önemli bir kısmını borçludan devir veya satın alan ve böylece ticari işletmesini veya işyerini işgal eden veya borçlunun işyerindeki ticari mallarının bir kısmını iktisapla beraber işyerini sonradan işgal eden bir üçüncü kişinin, borçlunun alacaklılarına zarar verme kastını bildiği farz olunur ${ }^{93}$. Bundan başka, bu hallerde

\footnotetext{
92،"Davaya konu 4 adet araç aynı gün ...tarihinde borç doğumundan sonra paket kaydı haczin yapıldığ kadar, haciz tarihinden önce satış yapılmış ise de oto alım satımı yapan, galerici olan 3 . şahıs adına uzun zamandır araç alımı satımı yapan ve vekili olan şahıslardan ....borçlu şirket ortak ve müdürlerinin akrabalarıdır. Hakkında yapılan borçlu şirketin ödeme yapamayacak durumda olduğunu bilebilecek durumdadırlar" HGK 30.05.2007 E:2007/21-295, K: 2007/319 (26.03.2009 www. kazanc1.com); “İ̈K'nun 280. maddesi 1 ve 3. fikralarına göre, tediye kabiliyetini kısmen veya tamamen kaybeden borçlunun iyiniyetli bir şahıstan beklenmeyecek tasarruflarla mevcudunu 2. derece kan hısmı olan kardeşine devretmek suretiyle eksiltmesi halinde yapılmış olan böyle bir tasarrufun tarafları kötü niyetli ve tasarruf batıl sayılır. Davalı, bu madde ile kabul edilen borçlu ve kendisi aleyhindeki karinenin aksini kanıtlayamamıştır.”15.HD 11.10.1984, E:2996, K:3006 (Akşener -İptal Davası s. 799).

93 "Somut olayda, borçlunun 3. kişiyle yaptığı markaların devrine ilişkin sözleşmeler İIY'nın 280.maddesinde belirtilen ticari işletmenin devri mahiyetindedir. Aynı madde uyarınca ticari işletmenin devri halinde devralan kişi borçlunun alacaklılarını zarara sokmak kastını bildiği ve borçlunun da bu hallerde zarar vermek kastı ile hareket ettiği kabul olunur ve bu şartlarda yapılan sözleşmeler de batıl sayılmaktadır"17.HD 9.07.2007, E: 2007/2474, K:2007/2410 (26.03.2009 www.hukukturk.com);“" Borçlunun üçüncü kişiyle yaptığı şirket devrine ilişkin sözleşme bir ticari işletmenin devri
} 
borçlunun da alacaklılarına zarar verme kastı ile hareket ettiği kabul olunur $^{94}$. Bu iki taraflı karine, ancak, iptal davasını açan alacaklıya sözü geçen devir, satış veya ticari işletmeyi ve işyerini terk tarihinden itibaren en az üç ay önce durumun yazılı olarak bildirildiğini veya ticari işletmenin bulunduğu yerde görülebilir levhalar asmakla beraber, ticaret sicili gazetesiyle, bu mümkün olmadığı takdirde bütün alacaklıların öğrenmelerini temin edecek şekilde münasip vasıtalarla ilân olduğunu ispat etmekle çürütülebilir (m.280/III).

Gürdoğan'a göre, karine, bir şahsın borçlunun işyerindeki malın, önemli olmasa dahi, sadece bir kısmını iktisap ederek aynı işyerini borçludan sonra işgal etmiş bulunması hâlinde de geçerlidir ${ }^{95}$.

Konunun daha iyi anlaşılması açısından, burada m. 280/III ile m. 44 arasındaki ilişkiyi ve her iki hükmün kapsamı ile uyguma alanlarını belirtmek yararlı olacaktır:

İcra ve İflâs Kanunu m. 44 uyarıca ticareti terk eden borçlu tacire keyfiyeti ticaret siciline bildirme ve mal beyanında bulunmak ve beyanın ödeme tarihinden itibaren iki ay süreyle malları üzerinde tasarruftan kaçınmak zorundadır. Tasarrufta bulunması hâlinde, sadece iyiniyetli üçüncü şahsın iktisabı korunur; karı ve koca ile usul ve füru, neseben veya sihen ikinci dereceye kadar (bu derece dahil) hisimlar, evlat edinenle evlatlık arasındaki iktisaplarda iyiniyet iddiası dinlenmez.

Gürdoğan'a göre, bu iki hüküm birbiriyle çelişmemektedir. Zira burada tacirin ticareti terki değil, ticarethanesinin devri hâli düzenlenmektedir. Diğer taraftan m. 44 tacirin ticareti terk etmesini müteakip iki ay süreyle haczi kabil mallarında tasarrufta bulunmasını

niteliğindedir. Bir ticari işletmenin devri halinde, işyerini sonradan işgal eden kişi, borçlunun alacaklılarını zarara sokmak kastını bildiği ve borçlunun da bu hallerde zarara sokmak kastı ile hareket ettiği kabul olunur." 15.HD 25.9.2002, E:4323, K:4183 (Güneren s. 1149).

${ }^{94}$ Peki borçlu ticari işletmesini değil de, sadece müşteri muhitini devretmesi halinde ve bunu da alacaklı, m. 280/IV' göre gerekli yerlere bildirmemişse; müşteri muhitini devralan kimseye karşı iptal davasının açılıp açılamayacağına ilişkin olarak bkz Umarİptal Davas1 s. 57-59.

${ }^{95}$ Gürdoğan -İflas Hukuku s. 235. 
önlemek amacına yönelmiştir; halbuki m. 280'de tacirin ticarethanesini devretmesi halinde bizatihi bu devir tasarrufunun iptali söz konusudur ${ }^{96}$.

Uyar, m. 44 ile m. 280/IV hükmünün içerik ve uygulama şartlarının birbirinden farklı olduğunu, alacaklının hacze gittiği işyerinin bir süre önce borçlu tarafindan m. 44/I'deki formalite yerine getirilmeden devredilmiş olduğunu haciz sırasında öğrenmesi varsayımında ne yapması gerektiğini şu şekilde açıklamaktadır: Eğer üçüncü şahıs, borçlunun yakını ise veya yakın çevresindeki kişilerden biri ise, alacaklı haciz yaptırıp, ona karşı istihkak davası açmalı ve bu davada borçlunun m. 44'e riayet etmeden yaptı̆̆ 1 devrin geçersizliğini ileri sürmelidir. Uyar, m. 280'e göre iptal davası açılabileceğini fakat bunun daha uzun sürmesi nedeniyle pratik olmadığını da beyan etmektedir. Eğer üçüncü şahıs az önce belirtilen şahıslardan birisi değilse, alacaklı o zaman doğrudan iptal davası açacak ve m. 280/IV'deki karineye dayanacaktır ${ }^{97}$.

Yargitay da, işyerinin devrinde m. 44 ve 280 'i birlikte ele alarak ticareti terk eden, yani işyerini devredenin anılan hükümlerde yer alan yükümlülüklere uymaması durumunda, devralanın alacaklıya karşı açtığ istihkak davasına karşı açılan iptal davasını (m.97/XVII) kabul etmektedir $^{98}$. Hal böyle olunca, işyeri, m.44 ve 280 'e aykırı şekilde devredilirse, devir, alacaklılara karşı geçerli olmayacak; alacaklı da, hâlen borçlunun malvarlığında bulunan işyerinin haczini talep edebilecektir ${ }^{99}$.

\section{3. Üçüncü Kişinin İyiniyetli Olmaması}

İyiniyet (Bona Fides, Guter Glaube), genel olarak bir kimsedeki dürüstlüğü ve iyi ahlâkı gösteren bir kavramdır. Türk Medeni Kanunun başlangıç hükümlerinde yer alan 3'üncü maddesi, hakların doğumuna, hüküm ve sonuçlarına uygulanacak ana ilkeyi koyar. Buna göre, kişilerin hak kazanırken namuslu ve dürüst davranmaları gerekmektedir ${ }^{100}$.

\footnotetext{
${ }^{96}$ Gürdoğan-Seminer s. 162.

${ }^{97}$ Uyar-Zarar Verme s. 21; Uyar-İptal Davas1 s. 118,119.

98 15.HD, 28.2.1994, E:5796, K:1128 (YKD 1995/5, s. 768,769).

99 21.HD, 11.9.1997, E:4917, K: 4989 (YKD 1998/11, s. 1574); 21.HD, 26.5.1998, E:3350, K:3902 (YKD 1999/11, s. 1576).

${ }^{100}$ Akipek, Jale/Akıntürk,Turgut: Türk Medeni Hukuku, Başlangıç Hükümleri-Kişiler Hukuku, C.I, 5.B., Ankara 2004, s. 156.
} 
Hakların geçerli bir şekilde kazanılabilmesi için gerekli olan şartlar, kanunlarla ve özellikle Türk Medeni Kanunu ile düzenlenir. Herhangi bir hak kazanılırken, o hakkın doğumu veya kazanılması için zorunlu olan şartların olayda mevcut olup olmadığının araştırılması gerekir. Kanundaki şartlara uyulmaksızın edinilmiş olan bir hak, geçerli bir surette kazanılmış olmaz. Ancak, bazen öyle durumlar söz konusu olabilir ki, orada hakkın kazanılması için gerekli olan şartların mevcut olup olmadığını anlamak hiç de kolay olmaz. Bütün dış görünüşler, hakkı kazanan kişide kanuni şartların olayda mevcut olduğu kanaatını uyandırabilir. Hakkı kazanan kimse bütün araştırmalarına karşın, hakkın kazanılmasını önleyen bir durumun varlığını anlayamaz; yani hakkı kazanırken kişide, hakkın kazanılması için gerekli olan bütün şartların olayda mevcut olduğu hususunda yanlış ve hatalı bilgi vardır ${ }^{101}$.

İşte iyiniyet, hakkın geçerli surette doğumunu veya kazanılmasını önleyecek bir durumun hak kazanılırken hakkı kazanan kişi tarafından bilinmesidir. Diğer bir deyişle, hakkın geçerli surette kazanılması için gerekli olan bir şartın veya hakkın geçerli surette kazanılmasını önleyen bir durumun hak kazanılırken böyle olayda varlığı veya yokluğu hakkında kişide mevcut hatalı ve yanlış bilgidir. Hak kazanılırken böyle bir bilgisizlik veya hatalı bilgiyle hareket eden kimse, iyiniyetlidir ${ }^{102}$.

\footnotetext{
${ }^{101}$ Akipek/Akıntürk s. 157.

${ }^{102}$ Akipek/Akıntürk s. 157; Hak kazanılırken hakkın kazanılmasını önleyen bir durumun olayda varlığı veya yokluğu hakkındaki her bilgisizlik, hakkı kazanan kişiyi iyiniyetli olarak kabul etmeye yetmez. Buna başka şartların da eklenmesi gereklidir. Gerçekten, bazı öyle durumlar olabilir ki, hak kazanan kimse biraz daha özenle davranmış olsaydı, biraz daha etraflı araştırmada bulunsaydı, hakkın kazanılması için gerekli olan şartların olayda mevcut olmadığını kolaylıkla anlayabilirdi. Bir kimsenin iyiniyet iddiasında bulunabilmesi için, bilgisizliğin veya yanlış bilginin onun ihmal veya kusurundan ileri gelmemiş olması şarttır. O kimse kendi kusuruyla yanılgıya düşmüş olmamalı, bu bilgisizliğini gidermek için hâl ve şartların gerekli kıldığı her şeyi yapmış bulunmalıdır. Kısaca, o kimsenin bilgisizliği hoş görülebilecek bir bilgisizlik mahiyetini arzetmelidir. Bazen kanundan ötürü belli hususlar hakkında mutlaka bilgi sahibi olmak zorunluluğu vardır. Kanundan ötürü bir şeyi bilmek zorunda olan kimsenin bilgisizliği hoş görülemez. Kanundan doğan bu bilme zorunluluğu özellikle şu hâllerde söz konusu olur: a-Kanun uyarınca ilân edilmesi zorunlu tutulan hususlar hakkında bilgisizlik ileri sürülemez. Herkes ilân edilmiş olan bu hususları kanun gereği öğrenmiş, dolayısıyla onu biliyor varsayılır. b- Kanunen açıklık (aleniyet) ilkesine tâbi tutulan sicillerdeki kayıtları da herkes bilmek zorundadır. Örneğin herkes tapu sicilindeki işlemleri kanundan ötürü bilmek zorundadır (Akipek/Akıntürk s. 157-160).
} 
İcra ve İflâs Kanunu'nun m. 280/I'e göre, borçlunun tasarrufta bulunduğu üçüncü kişi iyiniyetli (TMK m. 3) olmamalıdır. Öyle ki, borçlunun içinde bulunduğu mali durumun ve zarar verme kastının, tasarruf işleminin diğer tarafınca bilindiği veya bilmesini gerektiren açık emareler olmalıdır. Üçüncü kişinin, borçlunun kastını tasarrufi işlemin yapıldığ 1 sırada biliyor olması gerekir ${ }^{103}$.

Değişiklikten önce, m. 280/II'e göre, borçlunun, alacaklilara zarar vermek kastıyla yaptığı tasarrufların ancak lehine tasarruf yapılan üçüncü kişinin bu zarar verme kastını bilmesi hâlinde iptali mümkündü. Değişiklikten sonra ise, m.280'nin II.fikrası ilga edilerek, bu fikradaki "alacaklıları 1zrar kastı" (zarar verme kastı) maddenin ana unsuru haline dönüştürülmüş ve sadece bu kasıtla yapılan tasarrufların iptali mümkün hâle gelmiştir. Yani, kanun koyucu, bu konuda borçlunun kusurunu "bilen" alıcı yanında, "bilmesi gereken"e de yer vererek, mevcut koşullardan hâkimin sonuca varmasına olanak tanımıştır ${ }^{104}$. Diğer bir ifadeyle, borçlunun tasarrufta bulunduğu üçüncü kişi iyiniyetli olmamalıdır.

\section{Tasarruf İşleminden İtibaren Beş Yıl İçinde Borçlu Aleyhine Takip Yapılması}

Tasarruf işleminin yapıldığı tarihten itibaren beş yıl içinde borçlu aleyhine haciz ve iflâs yoluyla takibe girişilmiş olmalıdır. Diğer bir ifadeyle, malvarlığı borçlarına yetmeyen bir borçlunun, alacaklılarına zarar verme kastı ile tasarrufi işlemlerde bulunduğu üçüncü kişinin, borçlunun mali durumunu ve zarar verme kastını bilmesi veya bilmesini gerektiren açık emareler varsa, tasarrufi işlemler yapıldı ğı tarihten itibaren beş yıl içinde haciz veya iflâs yoluyla borçlu aleyhine takibe girişildiği takdirde, iptale tâbidir (m. 280/I). Ancak burada hemen şunu

\footnotetext{
${ }^{103}$ Muşul s. 1206.

104 "Davalı kooperatifin hükmü şahsiyeti devam etmekte ise de, davacıya olan kesinleşmiş borcunu ödemeden ortaklarına tapuda devir yapması ve borcunu ödememesi iyi niyetli bir davranış olarak kabul edilemez. Davalılar kooperatif ortakları olup borcun varlığını bilmesi gereken kişilerdir. $\mathrm{O}$ halde borçlu kooperatifin bu kişilere yapmış olduğu tasarruf IİK'nun 280. maddesi gereğince iptale tabidir"15.HD 30.05.2006, E:2006/422, K:2006/3181 (26.03.2009 www.hukukturk.com); 15.HD 19.02.2007 E: 2006/6667, K:2007/1004 (26.03.2009 www.hukukturk.com); 15.HD 05.07.2006 E:2006/2786, K: 2006/4194 (26.03.2009 www.hukukturk.com).
} 
belirtmek isteriz ki, buradaki süre m. 284'deki iptal hakkının ileri sürülmesinin sınırı olarak düzenlenen beş yıllık hak düşürücü süre ile karıştırılmamalıdır. Zira, m. 280/I'deki süre iptal hakkının doğumunun gereği olan süredir ${ }^{105}$.

Daha önceden de anlatıldığ üzere ${ }^{106}$, değişiklikten önce, m.280'de, kanun koyucu, borçlunun yaptığı tasarrufları zarar verme kastı ile yapıp yapmamasına göre farklı hükümlere tâbi tutmaktaydı. Borçlu tasarrufu zarar verme kastıyla yapmamışsa, m. 280/I'e tâbi tutulmaktaydı. Bu hükme göre, tasarrufun gerçekleştiği andan itibaren alacaklı iki sene içinde borçlu aleyhine haciz veya iflâs takibinde bulunmuş olması gerekiyordu ${ }^{107}$. Borçlu tasarrufunu zarar verme kastıyla yapmışsa, değişiklikten önceki maddenin II. fikrasına tâbi tutulmaktaydı ve bu tasarrufun iptali için herhangi bir süre ile sınırlamıyordu. Ancak, bu hüküm de, m. 284'deki beş yıllık hak düşürücü süre ile sınırlıydı.

Değişiklikten sonra ise, m.280'nin değişiklikten önceki I. ve II. fikralarının birleştirilerek ifade edildiği anlaşılmaktadır. Değişiklikten

önceki II. fikranın unsuru olan "alacaklıları 1zrar kastı" (zarar verme kastı) değişiklikten sonra maddenin ana unsuru haline dönüştürülmüş ve böylece bu kasıtla yapılan tasarrufların iptali yolu için, tasarrufi işlemlerin yapıldığ 1 tarihten itibaren beş y1l içinde haciz veya iflâs yoluyla borçlu aleyhine takibe girişilmesi zorunlu hâle getirilmiştir ${ }^{108}$.

\footnotetext{
${ }^{105}$ Üstündağ- İflâs Hukuku s. 225.

${ }^{106} \mathrm{Bkz} \S 2$, B,II,2,a.

107 "Taraflar arasındaki uyuşmazlık İIK'nun 277 ve devamı maddelerinde düzenlenen tasarrufun iptaline ilişkindir. Mahkemece borçlunun tasarrufu yaptı̆̆ sırada 8.10.1999 tarihi ile davanın açıldığı tarih arasında 2 seneden fazla bir zaman geçtiğinden bahisle dava reddedilmiştir. Karar davacı vekili tarafından temyiz edilmiştir. İIKK'nun 30.07.2003 tarihinde Resmi Gazete'de yayınlanarak yürürlüğe giren 4949 sayılı Yasa ile değişik 280. maddesinin.....fikraları gereğince yapılan işlemin iptaline karar verilmesi gerektiği ortadır. O halde, mahkemece aynı Kanunun 284. maddesi hükmünde öngörülen 5 senelik hak düşürücü sürenin de geçmemiş olduğu göz önüne alınarak, davanın kabulüne karar verilmesi gerekirken, İIK'nun 280/1 takibi arasındaki süre olduğu hususu da dikkatten kaçırılarak, tasarrufun yapıldığı tarih ile davanın açıldığı tarih arasında 2 seneden fazla zaman geçtiği gerekçesiyle davanın reddine karar verilmesi doğru olmamış, kararın bozulması gerekmiştir” 15.HD, 11.11.2003, E: 5210, K: 5372 (YKD 2004/4, s. 574-576).

108 “İcra ve İflâs Kanunu'nun 280. maddesinin ikinci fikrasında yer alan borçlunun birinci fikradaki tasarrufu, alacaklıları ızrar kastıyla yapması ve kasta üçüncü şahsın vukufu halinde, tasarruf tarihi ne olursa olsun batıl sayılır hükmü yürürlükten kaldırılarak, iptal
} 


\section{§ 3. ZARAR VERME KASTINDAN DOLAYI AÇILAN İPTAL DAVASININ YARGILAMA USÛLÜ}

Borçlunun alacaklısına zarar verme kastıyla yapmış olduğu tasarrufi işlemlerin iptal edilmesini isteyen alacaklı veya iflâs idaresi, bunun için sulh veya asliye hukuk mahkemesinde iptal davası açar. Hacizdeki iptal davası için görevli mahkeme, davacı alacaklının elindeki borç ödemeden aciz belgesinde ödenmemiş olarak gösterilen alacak miktarına göre, sulh hukuk veya asliye hukuk mahkemesidir. Buna karşllık iflâstaki iptal davasında görevli mahkeme, iptale tâbi tasarrufun tamamının değerine göre belirlenir. Tasarrufun miktar ve değeri Hukuk Usulü Muhakemeleri Kanununu m.8,I'deki parasal sınırdan ${ }^{109}$ az ise sulh hukuk, çok ise asliye hukuk mahkemesi görevlidir ${ }^{110}$. Mahkeme, iptal davasını, basit yargılama usulüne (HUMK m. 507-511) göre inceleyip karara bağlar (m.281/I). Burada şu hususu belirtmek isteriz ki, iptal davasının yargılama usûlü anlatılırken, yalnızca zarar verme kastına dayalı olan iptal davasının yargılama usulünün özellikleri dikkate alınıp, buna ilişkin açıklamalarda bulunulacaktır.

\section{A. İptal Davasının Konusu}

Daha önceden de vurgulandığ üzere $^{111}$, iptal davası ayni bir dava değildir; şahsi (kişisel) bir davadır. Diğer bir ifadeyle, iptal davası niteliği bakımından bir eda davasıdır ve normal bir hukuk davası gibi açılır.

İptal davasının konusu, iptale tâbi bir tasarruf ile borçlunun üçüncü kişiye devretmiş olduğu mal veya hak üzerinde, davacı alacaklının cebri icra yolu ile hakkını alma yetkisini elde etmesidir. Buna göre davacı, dava dilekçesinde, dava konusu tasarrufun, malvarlığı borçlarına yetmeyen borçlu tarafindan, kendisine zarar verme kastıyla yaptığını

davası için öngörülen beş yıllık hak düşürücü süre bu durumda da geçerli olduğundan ve aslında dava açma süresi azami beş yıl ile sınırlı olduğundan ve maddede yer alan iki yıllık sürenin 284. maddedeki süreye uyumlu hale getirilmesi nedeniyle bu değişikliğin yapılması..." (4949 sayılı Kanun 103. madde, madde gerekçesi ve genel gerekçesi).

${ }^{109} 6.330$ Lira olan meblağ, her yıl Maliye Bakanlığınca tespit ve ilân edilen "değerleme oranı"nda artırılarak uygulanacaktır. Ancak, bu uygulama nedeniyle mahkemeler görevsizlik kararı veremeyecektir (5236 s.K. m.19 ile HUMK'na ilave edilen Ek m.4).

${ }^{110} \mathrm{Kuru} /$ Arslan/Y1lmaz-İcra s. 623.

${ }^{111} \mathrm{Bkz} \S 1, \mathrm{~A}$. 
gösteren olayları, yani gerçek dava sebebini açıkça göstermelidir. Ancak, burada hemen şu hususu belirtmek isteriz ki, dava konusu tasarrufun, m.280' e göre iptalinin istendiğinin, yani davanın hukuki sebebinin, dava dilekçesinde gösterilmemiş olması, dava dilekçesinde kanuni bir noksanlık sayılmaz. Zira, hâkim, dava dilekçesinde kanun maddesi gösterilmiş olsa bile (m. 280), bu gösterme ile bağlı değildir; tasarrufun, m. 278-280'den hangisine göre iptal edilmesi gerektiğine kendisi karar verir. Çünkü, hâkim gerçek hukuki sebebi kendiliğinden araştırıp tespit etmekle yükümlüdür (HUMK m. 76).

Mal, lehine tasarruf yapılmış olan üçüncü kişinin elinde ise, iptal davasının konusu, o mal üzerinde cebri icraya müsaade edilmesi, yani davacı alacaklının alacağı için o malı haczedilip satılması veya iflâstaki iptal davasında, o malın borçlunun iflâs masasına verilmesidir. Lehine tasarruf yapılmış olan üçüncü kişi o malı elinden çıkarmış ve dördüncü kişi iyiniyetli olduğu için ona karşı iptal davası açılamıyor ise, o zaman davanın konusu, üçüncü kişinin o malın değeri nispetinde tazminata mahkum edilmesidir (m. 238/II).

\section{B. İptal Davasının Tarafları}

İptal davasını kimlerin açabileceğini tespit ederken, haciz ve iflâs hâllerini ayrı ayrı incelemek gerekir. Ancak belirtmeliyiz ki, kimlerin iptal davası açabileceği, m. 277'de tahdidi olarak sayılmıştır.

\section{Hacizdeki İptal Davası}

\section{Davacı}

Hacizdeki iptal davasında davacı, elinde kesin veya geçici borç ödemeden aciz belgesi bulunan alacaklıdır (m. 277/1). Diğer bir ifadeyle, haciz yolu ile takipte, iptal davasını, borçlunun mallarına konulan haciz sonucunda alacağını tamamen veya kısmen alamamış olan haciz alacaklısı açar. Haciz alacaklısının alacağını tamamen veya kısmen alamamış olduğu, borçlu hakkında alınmış olan borç ödemeden aciz belgesi ile ispat edilebilir ${ }^{112}$.

${ }^{112}$ Bu konu hakkında bkz § 1, D,I; Alacakl1, aciz belgesi ibraz mecbur olmaksızın, sadece karşılık dava olarak, iptal davasını icra mahkemesinde açabilir (m. 97/XVII). 
Ayrıca iptal davası açmak hakkı münhasıran şahsa bağlı haklardan olmadığından, aciz belgesinde gösterilen alacağı cüz'i veya külli halefiyet yoluyla iktisap edenler de bu hakkı kullanabilir ${ }^{113}$.

\section{Davalı}

Hacizde iptal davası, borçlu ve iptale tâbi tasarruf lehine olan üçüncü kişiler aleyhine açılır (m. 282 c.1). Buna göre, iptal davasında, zarar verme kastıyla tasarruf işlemini yapan borçlu ve lehine tasarruf yapılan üçüncü kişi, davalı taraf bakımından şekli bakımından mecburi dava arkadaşı durumundadırlar ${ }^{114}$. Daha önceden de vurgulandığı üzere, $\mathrm{m}$. 280/I'e göre, davacının zarar verme kastına dayalı iptal davasının açılabilmesi için, borçlunun tasarrufta bulunduğu üçüncü kişi iyiniyetli (TMK m. 3) olmamalidir ${ }^{115}$.

Lehine tasarruf yapılan üçüncü kişi, iptale tâbi tasarruf ile iktisap ettiği mal veya hakkı başka bir dördüncü kişiye devretmiş ve bu dördüncü kişi kötüniyetli ise, o dördüncü kişi de iptal davasında davalı gösterilmelidir (m. 282 c. 2). Davacı alacakl1, dördüncü kişinin kötü niyetli olduğunu, yani dava konusu malı veya hakk1 kendisine devreden üçüncü kişi ile borçlu arasındaki tasarrufun iptale tâbi olduğunu bildiğini, ispat etmekle yükümlüdür ${ }^{116}$.

\section{II. İflâstaki İptal Davası}

\section{Davacı}

İflâsta iptal davası açmak hakkı, iflâsın açılması ile, iflâs masasına intikal eder (m. 187). Bu sebeple, iflâsta zarar verme kastına dayalı iptal davasını (m.280) açmak hakkı, iflâs masasın kanuni temsilcisi olan (m. 226) iflâs idaresine aittir (m. 277/II; m. 187). İflâsta iptal davasını açan

${ }^{113}$ Gürdoğan-İflâs Hukuku s. 240; Berkin s. 328; Belgesay s. 170.

${ }^{114}$ Kuru/Arslan/Yılmaz s. 622; "Davacı, iptal dilekçesinde yalnız borçluyu veya yalnız üçüncü kişiyi davalı göstermiş ise, iptal davası, pasif husumet ehliyetinin noksan olduğundan dolayı reddedilmez. Bu halde, Mahkemenin, davayı diğer mecburi dava arkadaşına, üçüncü kişiye veya borçluya da teşmil edilmesi için davacıya bir süre vermesi, davacı bu süre içinde davayı diğer mecburi dava arkadaşına da teşmil ederse, davaya devam etmesi gerekir" (Kuru-El Kitabı s. 1216).

${ }^{115} \mathrm{Bkz} \S 2$,B,II,3.

${ }^{116}$ Kuru-El Kitabi s. 1216; Bkz 15.HD 11.5.2000, E:532, K:2327 (YKD 2000/9, s. 13961397). 
iflâs idaresinden, aciz belgesi ibraz etmesi istenmez; başka bir deyişle, iflâsta iptal davası açılabilmesi için, aciz belgesi ibraz edilmesine gerek yoktur.

Ayrıca, ikinci veya daha sonraki alacaklılar toplantısında, iptal davasının iflâs idaresi tarafından açılmasına gerek görülmezse, iptal davası açmak hakkı, isteyen alacaklıya veya alacaklılara devredilir (m. 245). Bu halde zarar verme kastına dayalı iptal davası, dava açma hakkı kendisine devredilen alacaklı veya alacaklılar tarafindan açılır (m. $277 / 2)^{117}$.

\section{Davalı}

$\mathrm{Bu}$ halde, borçlu iflâs etmiş olduğundan, iptal davasının aynı zamanda borçlu (müflis) aleyhine açılmasına olanak yoktur. İflâstaki iptal davasının, yalnız lehine tasarruf yapılan üçüncü kişi ve varsa dördüncü kişi aleyhine açılması gerekir ${ }^{118}$.

Borçlu veya lehine tasarruf yapılan üçüncü kişi ölmüş ise, iptal davası, iptal davası, bu kişilerin mirasçıları aleyhine açı1ır (m.282 c.1).

\section{Deliller ve Delillerin Takdiri}

Hukukumuzda hakimin bir vakıa iddiasını ispatlamış sayabilmesi için kural olarak, o vakıanın doğruluğu konusunda kanaat sahip olması gerektiği kabul edilmektedir. Bu kanaatin derecesi, yani tam kanaat mi, yoksa yaklaşık kanaat mi arandığ 1 ise ispat ölçüsünü ilgilendirir ve hukukumuzda genellikle kabul edildiği üzere tam kanaat ulaşımı kural, yaklaşık kanaat ulaşımı ise istisnadır. İspat ölçüsünün düşürülmesi ve yaklaşık ispat ile yetinilmesi, ancak takdiri delillerle ispatın caiz olduğu durumlar için geçerli olup, kesin delillerle ispat zorunluluğu bulunan hallerde ispat ölçüsünün düşürülmesi söz konusu olamaz ${ }^{119}$. Buna göre,

117 "Alacaklılar, iflâs kapandıktan sonra iptal davası açabilirler; ancak, bu iptal davası iflâsta alınmış olan borç ödenmeden aciz belgesi ile açılamaz. Bir veya birkaç alacaklının, iflâstan sonra iptal davası açabilmesi için de, iptal davası açma hakkının, kendisine davacı alacaklıya veya alacaklılara devredilmesi gerekir"(Kuru-El Kitabı s. 1215).

${ }^{118}$ Kuru- El Kitabı s. 1216; Gürdoğan-İflâs Hukuku s. 249.

119 Atalay-Menfi Vakıa s. 43; Pekcanıtez,Hakan/Atalay,Oğuz/Özekes,Muhammet: Medenî Usûl Hukuku, 6.B., Ankara 2007, s. 438,439. 
ispat faaliyetinin içeriği bakımından ispat, doğrudan ve dolaylı ispat olarak ikiye ayrılır. İspat, doğrudan iddia olunan vakıaya delalet edici deliller aracılığıyla yapılırsa buna doğrudan ispat denir ${ }^{120}$. İddia edilen vakıayı doğrudan yansıtan ve kendisinden vakıanın oluşu hakkında doğrudan kanaat edinebilecek delillerle değil, emare teşkil eden diğer komşu vakıaların varlığına dayanarak çekişmeli vakıa hakkında hakim tarafından bir sonuca varılması yoluyla ispata çalışmak ise dolaylı ispat (emare ile ispat) olarak adlandırılır ${ }^{121}$.

Genel hatları ile emare, Konuralp, tarafindan şu şekilde tanımlanmıştır: "Bir iddianın doğrulanması konusunda kanaat edinmeye elverişli olan ve fakat temsili niteliği itibariyle iddia edilen vakıayı ancak ihtimal derecesinde veya kısmen doğrulayabilen ispat araçlarına emare denir" ${ }^{\prime 22}$.

Yukarıda yaptığımız açıklamalar üzerine, mahkeme, zarar verme kastına dayalı açılmış olan iptal davalarına ilişkin uyuşmazlıkları, hâl ve şartları göz önünde tutarak serbestçe takdir eder ve çözer (m. 281/I). Buna göre, mahkeme özellikle bir tasarrufun m. 280 hükmü gereğince iptale tâbi olup olmadığını serbestçe takdir eder. Mahkemenin bu serbest takdir hakk1, delille özellikle Hukuk Usûlü Muhakemeleri Kanunu'nun deliller için koyduğu sınırlamalar ile bağlı olmaksızın her türlü delille, özellikle tanık delilline dayanarak hüküm verebileceğini de kapsar ${ }^{123}$.

${ }^{120}$ Umar/Yılmaz s. 2, dpn 5.

121 Üstündağ- Yargılama s. 621; Yıldırım, M. Kâmil: Medeni Usul Hukukunda Delillerin Değerlendirilmesi, İstanbul 1990, s. 121.

${ }^{122}$ Konuralp, Halûk: İspat Kurallarının Zorlanan Sinırları, Ankara 1999, s. 29; Kunter'e göre, emare (belirti), dış dünyada varlığı olan bir olaydır ve mahkemeler dava konusu olay1 belirlemede bunlardan yararlanabilirler. $\mathrm{Bu}$ nedenle belirtinin bir delil çeşidi olduğunda tereddüt edilmemelidir. Belirtiler ispat edilecek olayı dolayısı ile gösterirler. Örneğin fren izinden otomobilin hızını ögrenebiliriz. Yine Kunter'e göre, emareler tek başına ispat kuvvetini haiz olmadıkları gibi, birlikte, birbirlerini tamamladıkları takdirde delil sayılabileceklerdir (Kunter,Nurullah/Yenisey/Feridun/Nuhoğlu, Ayșe :Muhakeme Hukuku Dalı Olarak Ceza Muhakemesi Hukuku, İstanbul 2006, s. $657,658)$

${ }^{123}$ Kuru-El Kitabı s. 1220; "Bu bağlamda davalılar satış bedelinin tapuda daha az harç ödemek için düşük gösterildiğini tanıkla ispatlayamazlar.” (Öztek, Selçuk: Tasarrufun İptali Davalarında Ortaya Çıkan Bazı Sorunlar ve Yargıtay'ın Bu Sorunlara İlişkin Uygulamaları: Prof. Dr. Ergun Önen'e Armağan, İstanbul 2003, s. 320);“ tapulu taşınmazın satışı tapu sicil muhafızlığında resmi şekilde düzenlemiş ve davalıların akit tablosunda imzaları mevcuttur. ...Bu resmi kaydın aksini akdi yapan davalılar tanıkla 
Buna göre, zarar verme kastından dolayı iptal davasında, davacı, kendi borçlusunun borca batık bir halde iken işlem yaptığını ve zarar verme kastı taşıdığını, ayrıca işlemin diğer tarafı olan kişinin de takip borçlusunun mali durumunu ve zarar verme kastını bildiği ve bilmesi gerektiğini ispat etmelidir. Burada davacının ispat yükünü yerine getirmesi, özellikle delil ikame yükünü yerine getirmesi bazen oldukça güç olacağından, kanun koyucu alacaklının ispat yükünü hafifletecek bazı karineler getirmiştir ${ }^{124}$.

Burada hem mali durumun, yani borca batıklı̆̆ın hem de zarar verme kastının ispatında yaklaşık ispat ölçüsü geçerlidir; tam ispat aranmaz. Zarar verme kastının bulunması, deruni bir olay olduğundan, bu kastın dışa vurumunu ifade eden olaylar göz önüne alınarak, makul bir kişinin, dava konusu tasarrufun alacaklıları zarara uğratacağını anlayabileceği durumlarda kastın mevcudiyetine hükmedilir ${ }^{125}$.

Özellikle işlem lehine olan tarafın, takip borçlusunun malî durumunu ve kastını bildiği veya bilmesi gerektiği olayı, emareler yoluyla dolaylı olarak ispatlanabilecek bir husustur. Tasarruftan yararlanan tarafin, borçlunun ilişkilerini ve yaşama biçimini bilen ve bu nedenle, daha önceki durumuna nazaran, işlemin yapıldığı sırada malî yönden kötü durumda bulunduğunu, örneğin, mallarını ucuz fiyatlarla elden çıkarmaya çalıştığını, hakkında çok sayıda ya da önemli miktarda icra takipleri bulunduğunu, iş yerinde ve evinde haciz uygulandığını vb. bildiği veya bilmesini gerektirecek açık emarelerin bulunduğu ortaya konularak ispat yükü yerine getirilebilirr ${ }^{126}$. Diğer bir ifadeyle, yukarıda da belirttiğimiz üzere, kanun koyucu zarar verme kastından dolayı açılan bir iptal davasında emareler yoluyla ispatı yeterli görmüştür.

kanıtlayamazlar, yazılı belge ile ispatlaması gerekir"15.HD 6.5.1991, E:1073, K: 2298 (Ertekin,Erol/ Karataş,İzzet: İstihkak ve Tasarrufun İptali Davaları, Ankara 1995, s. 693).

${ }^{124}$ Pekcanıtez/Atalay//Sungurtekin-Özkan/Özekes -İcra s. 558.

${ }^{125}$ Pekcanıtez/Atalay/Sungurtekin-Özkan/Özekes -İcra s. 558.

126 Pekcanitez/Atalay/Özekes/Sungurtekin-Özkan-İcra s. 558,559; Kuru-El Kitabı s. 1206. 


\section{D. İptal Davası Açma Süresi}

İptal davalarında iki çeşit süreye yer verilmiştir. Birincisi iptal hakkının doğumunun gereği olan süredir. 280. maddede, borçlunun alacaklılarına zarar verme kastıyla yaptığı tüm işlemlerin iptalinin istenebilmesi için işlemin gerçekleştiği tarihten itibaren beş y1l içinde borçlu aleyhine bir takipte bulunma zorunluluğu vardır. Bu maddede düzenlenen nedenlerle tasarrufun iptali davası açılabilmesi ve bu davanın dinlenebilmesi için iptal davasından önce işlem tarihinden itibaren beş yıl içinde borçlu aleyhine bir haciz veya iflâs takibi yapılması gereklidir ${ }^{127}$.

İkinci çeşit süre ise, doğan iptal talebinin ileri sürülmesinin sınırı olarak düzenlenmiştir. Diğer bir ifadeyle, birinci süreye göre (m.280) doğan iptal talebi de ancak belli bir süre içinde ileri sürülebilecek ve aksi halde ise dinlenmeyecektir ${ }^{128}$. Bu sonuncu açısından (m.284) iptal davası beş yıllık hak düşürücü süreye tâbidir ve bu nedenle kendiliğinden gözetilir. $\mathrm{Bu}$ süre borçlandırıcı işlemin değil, tasarrufi işlemin yapıldığı tarihten itibaren beş yıl geçmekle düşer ${ }^{129}$. Bu süre 280 'inci maddede düzenlenen beş yıllık süreden farklıdır. 280'inci madde, borçlunun alacaklılarına zarar verme kastıyla yaptığı tüm işlemlerin iptalinin istenebilmesi için işlemin gerçekleştiği tarihten itibaren beş y1l içinde borçlu aleyhine bir takipte bulunma zorunluluğu ile ilgilidir. Diğer bir ifadeyle 280'inci maddede düzenlenen nedenlerle bir tasarrufun iptali davası aç1labilmesi ve bu davanın dinlenebilmesi için tasarruf tarihinden itibaren beş yıl içinde iptal davasından önce borçlu aleyhine bir haciz veya iflâs takibi yapılması da gerekecektir ${ }^{130}$.

Buna göre, alacaklı, m. 280/I'e göre iptale tâbi tasarrufun yapıldığ1 tarihten itibaren, beş yıl içinde borçluya karşı icra veya iflâs takibi yapmış ise, tasarrufun yapıldığı tarihten itibaren beş yıl içinde iptal davası açabilir (m. 284).

${ }^{127}$ Üstündağ- İflâs Hukuku s. 225; Kuru-El Kitabı s. 1219; Kuru/Arslan/Yılmaz s. 624.

128 Üstündağ- İflâs Hukuku s. 225; Kuru-El Kitabı s. 1219.

129 Kuru-El Kitabi $\quad$ s. 1218;"ZZira sadece iltizami muamele yapılmış ise, iltizami muameleye konu teşkil eden mal alacaklının cebri icra yolu ile takibi üzerine vazedilecek hacze bizzat konu teşkil edebileceği gibi; iflâs yolu ile takip halinde ise masaya girecektir. Bu sonuncu durumda iflâs idaresi artık tasarrufi muameleyi yapmaktan kaçınacaktır" (Üstündağ- İflâs Hukuku s. 225).

${ }^{130} \mathrm{Kuru} / \mathrm{Arslan} /$ Y1lmaz-İ́cra s. 624. 


\section{§. 4. İPTAL DAVASININ SONUÇLARI}

Davacının, zarar verme kastına dayalı açmış olduğu iptal davasını kaybetmesi hâlinde, diğer bütün hukuk davalarında olduğu gibi, iptal davasını kaybeden davacı davalılara yargılama gideri ödemeye mahkum edilir. Aşağıda, davacının zarar verme kastına dayalı açmış olduğu iptal davasını kazanmasının sonuçları incelenecektir.

\section{A. Hacizdeki İptal Davasının Sonuçları}

Davacı alacaklı, iptal davasını kazanınca, dava konusu olan mal borçlunun mülkiyetine geri dönmez. Davalı üçüncü kişi, gene o malın maliki olarak kalmakta devam eder. Yalnız, iptal edilmiş olan tasarruf, iptal davasını açmış ve kazanmış olan alacaklıya karşı hüküm ifade etmez; yani, yalnız bu alacaklı bakımından iptal edilmiş sayılır ${ }^{131}$. İptal davasını kazanan alacaklı, tasarruf konusu mal sanki borçlunun mülkiyetindeymiş gibi, onu cebri icraya dahil etmek, haczettirmek hakkını kazanır (m. 283).

Buna göre, hacizde iptal davasını kazanan alacaklı, tasarruf konusu malı borçlununmuş gibi haczettirir, sattırır ve elde edilen paradan alacağını alır. Geriye para artarsa, bu para, borçluya değil, üçüncü kişiye verilir.

İptal davası, üçüncü kişinin elinden çıkarmış olduğu değere ilişkin ise, üçüncü kişi, bu değer oranında nakden tazminata mahkum edilir (m. 283/II). Bu halde, davacı alacaklı iptal davası sonucunda alacağı ilâmı doğrudan doğruya davalı üçüncü kişiye karşı icraya koyarak alacağına kavuşur.

\section{B. İflâstaki İptal Davasının Sonuçları}

İflâstaki iptal davasının sonunda ise, davalı üçüncü kişi, iptal edilen tasarrufla elde ettiği şeyi iflâs masasına vermekle yükümlüdür. İptal davası, bu hak kendisine devredilmiş bir alacaklı tarafından açılmış olsa

\footnotetext{
131 “Tasarrufun iptali davalarında amaç, dava konusu taşınmazın üzerine haciz uygulanıp satışın temini bakımından alacaklıya yetki verilmesi, satış bedelinden artan bir miktar olduğu takdirde satın alan davalıya verilmesinden ibaret olup, ayrıca tapu kayıtlarının iptaline gerek bulunmamaktadır" 15.HD 25.04.2007, E:2006/4715, K:2007/2734 (26.03.2009 www.hukukturk.com); Aynı yönde kararlar için bkz 15.HD 19.04.2007, E: 2006/694, K.2007/2563 (26.03.2009 www.hukukturk.com).
} 
bile, davalı bu alacaklının alacağını ödeyerek davayı sona erdiremez. Aldığı şey veya paranın tamamını iade etmek zorundadır (m. 245).

Üçüncü kişinin, iptale tâbi tasarrufla edindiği ve masaya iade ettiği mala karşılık verdiği şey masada aynen mevcut ise, bu karşıllk, kendisine masa borcu olarak iade edilir. Bu mümkün değilse, üçüncü kişi haklarını muhafaza ettiğinden, iade ettiği malın bedelini masaya iflâs alacağı olarak yazdıracaktır ${ }^{132}$.

\section{SONUÇ}

Haciz yoluyla takiplerde hacizden, iflâs yoluyla takiplerde ise iflâsın açılmasından önce borçlunun mal ve hakları üzerinde bir sınırlama bulunmamaktadır. Bunun sonucu olarak, bazen borçlular, mallarına haciz konulması veya iflâs kararı verilmesi ihtimali bulunan durumlarda, çoğu kez alacaklılardan mal kaçırmak için veya bu niyet olmasa bile şüpheli bir takım işlemlerle tasarruflarda bulunabilirler. Borçlunun bu tasarrufları, herhangi bir kısıtlama söz konusu olmadığından geçerlidir. $\mathrm{Bu}$ tasarruflar, yaptıkları takiplerle borçlunun başka mallarından alacaklarını alabildikleri ölçüde alacaklıları ilgilendirmez. İşte, bir borçlunun, mallarının haczinden veya iflâs etmeden önce, alacaklılarından mal kaçırmak için yapmış olduğu şüpheli tasarrufların iptal ettirilebilmesi için, alacaklılara bir dava açma hakkı tanınmıştır ki, buna iptal davas1 (Anfechtungsklage) denir (m. 277-284). Buradaki tasarruf kavramını, doktrindeki görüşe uygun olarak, borçlunun malvarlığını azaltıcı nitelikte bulunan hukuki işlemleri ve hukuki fiillerini de içerir şekilde en geniş anlamıyla kabul etmek gerekir. Zira, Kaynak İsviçre Kanunu (SchKG Art.285 vd)'nda ve Alman Kanunları'nda da tasarrufun iptali davasının konusu, borçlu tarafindan yapılan hukuki fiillerdir (Rechtshandlungen).

İcra ve İflâs Kanunu, borçlunun iptale tâbi tasarruflarını üç grup altında düzenlemektedir (m. 278-280). Biz bu çalışmamızda, m. 280'de düzenlenen zarar verme kastından dolayı iptal davasını, 4949 sayılı Kanunla değiştirilmesinden önceki ve sonraki hâlini karşılaştırmalı olarak inceledik.

${ }^{132}$ Pekcanıtez/Atalay/Sungurtekin-Özkan/Özekes-İcra s. 571. 
İcra ve İflâs Kanunu m. 280 değişiklikten önce Kaynak İsviçre Kanunun'dan (SchKG Art.288) farklı ve daha karmaşıktı. Ancak 4949 sayılı Kanunun m. 66 ile İcra ve İflâs Kanunu'nun m. 280'nin I.fikrası değiştirildiğinden ve m. 103 ile II.fikrası ilga edildiğinden dolayı, m. 280 ile Kaynak İsviçre Kanunu (SchKG) Art. 288 ile paralel hale getirilmiştir. Nitekim bu durum madde gerekçesinde de belirtilmiştir.

Değişiklikten önce, "diğer butlan halleri" olan madde başlığ 1 "zarar verme kastından dolayı iptal" olarak değiştirilmiştir.

Değişiklikten önce, m. 280, borçlunun yaptığı tasarrufları zarar verme kastı ile yapıp yapmamasına göre farklı hükümlere tâbi tutmaktaydı. Borçlu tasarrufunu zarar verme kastıyla yapmışsa, değişiklikten önceki maddenin II. fikrasına tâbi tutulmaktaydı. Diğer bir ifadeyle tediye kabiliyetini kısmen veya tamamen kaybetmiş olan borçlunun, iyiniyetli bir kişiden veya basiretli bir tacirden beklenilmeyecek tasarruflarla mevcudunu eksiltmesi, bu tasarrufları alacaklılarına zarar vermek kastiyla yapması ve lehine tasarruf yapılan üçüncü kişinin bu zarar verme kastını bilmesi hâlinde, bu tasarrufları, tarihi ne olursa olsun iptale tâbi tutmaktaydı.

Değişiklikten sonra ise, m. 280'nin değişiklikten önceki I.ve II. fikralarının birleştirilerek ifade edildiği anlaşılmaktadır. Şöyle ki değiştirilmeden önceki I. fikrada bulunan "iyiniyetli bir şahıstan veya basiretli bir tacirden beklenilmeyecek tasarruflar" unsurunun maddeden çıkarıldığı görülmektedir. Değişiklikten önceki II. fikranın unsuru olan "alacaklıları ızrar kastı" (alacaklılara zarar verme kastı) değişiklikten sonra maddenin ana unsuru hâline dönüştürülmüş ve sadece bu kasitla yapılan tasarrufların iptali mümkün hâle gelmiştir. Kanaatimizce, "iyiniyetli bir şahıstan veya basiretli bir tacirden beklenilmeyecek tasarruflarla mevcudun eksiltilmesi" şeklindeki ölçüt objektiflikten uzak ve alacaklının mağduriyetini doğuran bir kavramdı. Bu kavramın yerine Kaynak İsviçre Kanunu'ndaki (SchKG Art.288) gibi, "alacaklılara zarar verme kastı" (Schädigungsabsicht- Benachteilungsabsicht) unsurunun kabul edilerek maddenin bu şekilde düzenlenmesi yerinde olmuştur.

Değişiklikten önce kanun koyucu, m. 280'de borçlunun yaptı̆̆ 1 tasarrufları zarar verme kastı ile yapıp yapmamasına göre farklı 
hükümlere tâbi tutmaktaydı. Borçlu tasarrufu zarar verme kastıyla yapmamışsa, m. 280/I'e tâbi tutulmaktaydı. Bu hükme göre, tasarrufun gerçekleştiği andan itibaren alacaklının iki sene içinde borçlu aleyhine haciz veya iflâs takibinde bulunmuş olması gerekiyordu. Borçlu tasarrufunu zarar verme kastıyla yapmışsa, değişiklikten önceki maddenin II.fikrasına tâbi tutulmaktaydı ve bu tasarrufun iptali için herhangi bir süre ile sınırlamıyordu. Ancak, bu hüküm de, m. 284'deki beş yıllık hak düşürücü süre ile sınırlıydı.

Değişiklikten sonra ise, m. 280'nin değişiklikten önceki I. ve II. fikralarının birleştirilerek ifade edildiği anlaşılmaktadır. Değişiklikten önceki II.fikranın unsuru olan "alacaklıları 1zrar kastı" (zarar verme kastı) değişiklikten sonra maddenin ana unsuru hâline dönüştürülmüş ve böylece bu kasitla yapılan tasarrufların iptali yolu için, tasarrufi işlemlerin yapıldığı tarihten itibaren beş yıl içinde haciz veya iflâs yoluyla borçlu aleyhine takibe girişilmesi zorunlu hale getirilmiştir. $\mathrm{Bu}$ alacaklılar lehine yapılmış bir değişikliktir. Kanaatimizce, iptal davalarında hak düşürücü süreyi beş yıl olarak belirleyen m. 284 ile de bir paralellik sağlandığından, bu değişiklik yerinde olmuştur.

Değişiklikten önce, m. 280/II'e göre, borçlunun alacaklılara zarar vermek kastıyla yaptığ 1 tasarruflar ancak lehine tasarruf yapılan üçüncü kişinin bu zarar verme kastını bilmesi hâlinde iptali mümkündü. Değişiklikten sonra ise, m. 280'nin II.fikrası ilga edilerek, bu fikradaki "alacaklıkları ızrar kastı" (zarar verme kastı) maddenin ana unsuru hâline dönüştürülmüş ve sadece bu kasıtla yapılan tasarrufların iptali mümkün hâle gelmiştir. Yani, kanun koyucu, bu konuda borçlunun kusurunu "bilen" alıcı yanında, "bilmesi gerekene" de yer vererek, mevcut koşullardan hâkimin sonuca varmasına olanak tanımıştır.

Değişiklikten önce, m. 280'nin I.fikrasında, borçlunun tasarrufu yaptığı sırada; borçlunun, "ödeme gücünü kısmen ya da tamamen kaybetmiş olması", yahut "hakkında İcra ve İflâs Kanunu m. 178/III'deki koşulların gerçekleşmiş olması" gerektiğinden bahsedilmekteydi. Zira bu maddede yer alan borçlunun "ödeme gücünü kısmen ya da tamamen kaybetmiş olması" ile neyin anlatılmak istendiği pek açık değildi. Doktrinde kabul edildiği üzere, kanun koyucunun burada " borca batıklık" (Überschuldung), “aciz hâli” (Zahlungsunfähigkeit), 
"ödemelerin durdurulması" (Zahlungseinstellung) olaylarından herhangi birinin ortaya çıkmasını $\operatorname{arad}_{\mathfrak{g}} 1$ belirtilmekteydi. Kanaatimizce değişiklikten sonra, maddenin "malvarlığı borçlarına yetmeyen" tabiri ile, kanun koyucu burada artık yalnızca borçlunun borca batık olması hâlini esas almıștır.

Son olarak, 4949 sayılı Kanunla m. 280'de yapılan değişikliklerle, madde daha kapsamlı ve genel bir tasarruf işleminin iptal edilebilme hâlini almıştır. 


\section{KISALTMALAR CETVELI}

\begin{tabular}{|c|c|}
\hline ABD & : Ankara Barosu Dergisi \\
\hline AnfG & $\begin{array}{l}\text { :Gesetz über die Anfechtung von } \\
\text { Rechtshandlungen eines Schuldners } \\
\text { außerhalb des Insolvenzverfahrens } \\
\text { (Anfechtungsgesetz) }\end{array}$ \\
\hline Art. & :Artikel \\
\hline Aşa. & : Aşağı \\
\hline Aufl & :Auflage \\
\hline B. & : Bask1 \\
\hline Batider & : Banka ve Ticaret Hukuku Dergisi \\
\hline BK & : Borçlar Kanunu \\
\hline Bkz & : Bakınız \\
\hline b. & :Bent \\
\hline C. & : Cilt \\
\hline c. & : cümle \\
\hline Çev. & : Çeviren \\
\hline dpn & : Dipnot \\
\hline D. & : Dergi \\
\hline $\mathbf{E}$ & : Esas \\
\hline f. & :F1kra \\
\hline HD & : Yargitay Hukuk Dairesi \\
\hline HGK & : Yargitay Hukuk Genel Kurulu \\
\hline HUMK & : Hukuk Usulü Muhakemeleri Kanununu \\
\hline InsO & : Insolvenzordnung \\
\hline
\end{tabular}


İBD

iiid

ïK

İKY

İKì

İzBD

$\mathbf{K}$

LHD

LMUiïHD

m

MBD

TBMM

TMK

TTK

RG

RKD

s.

SchKG

s.K.

TBMM

vb

vd
: İstanbul Barosu Dergisi

: İcra ve İflâs Dairesi

:İcra ve İflâs Kanunu

: İcra ve İflâs Kanunu Yönetmeliği

: İlmi ve Kazai İçtihatlar Dergisi

:İzmir Barosu Dergisi

: Karar

:Legal Hukuk Dergisi

: Legal Medenî Usûl ve İcra İflâs Hukuku Dergisi

: madde*

: Manisa Barosu Dergisi

:Türkiye Büyük Millet Meclisi

: Türk Medeni Kanunu

: Türk Ticaret Kanunu

: Resmi Gazete

: Resmi Kararlar Dergisi

: Sayfa

: Bundesgesetz über Schuldbetreibung und Konkurs

: Sayıl1 Kanun

:Türkiye Büyük Millet Meclisi

: ve benzeri

: ve devamı

* "m” kısaltması, kural olarak İcra ve İflâs Kanunu maddelerini göstermektedir. Başka bir kanun maddesi belirtiliyorsa, ilgili kanun ismi " $m$ " kısaltmasından önce belirtilmiștir. Örneğin TMK m. gibi. 
YHD

YHMİD

YKD

Yuk

YÜHFD
:Yasa Hukuk Dergisi

: Yasa Hukuk ve İçtihat ve Mevzuat Dergisi

:Yargitay Kararları Dergisi

: Yukarı

: Yeditepe Üniversitesi Hukuk Fakültesi Dergisi 


\section{KAYNAKÇA*}

•AKİPEK,Jale/AKINTÜRK,Turgut: Türk Medeni Hukuku, Başlangıç Hükümleri-Kişiler Hukuku, C.I, 5.B., Ankara 2004.

-AKKAYA,Tolga: "Alacaklıdan Mal Kaçırmaya Yönelik Muvazaalı Tasarrufların İcra ve İflâs Kanunu'nda Düzenlenen İptal Davasına Konu Olup Olamayacağı Sorunu", LMUİ̈HD 2006/3, s. 661-684.

-AKŞENER, Haşmet Sirrı: İcra ve İflâs Hukukunda Tasarrufun İptali Davaları, İstanbul 2002 (Akşener-İptal Davası).

-AKŞENER, Haşmet Sırrı: İIY'nın 280. Maddesinde 4949 Sayılı Yasa İle Yapılan Değişiklik Üzerine Bir İnceleme, LHD 2003/9, s. 22092212 (Akşener- İptal).

-AKŞENER, Haşmet Sırrı: Tasarrufun İptali Davalarında Aciz Belgesi, LHD 2003/1, s. 51-56 (Akşener-Aciz Belgesi).

-AKYAZAN, Sitkı: Türk Hukukunda İptal Davasi, AD 1963/3-4, s. 235248.

-AMONN, Kurt/ GASSER, Dominik: Grundriss des Schuldbetreibungs- und Konkursrecht, 6. Aufl., Bern 1997.

-ANSAY, Sabri Şakir : Hukuk İcra ve İflâs Usulleri, 3.B., Ankara 1954.

-ASLAN, Kudret : Hacizde İstihkak Davası, Ankara 2005.

-ATALAY, Oğuz : Anonim Şirketlerin İflâsı, İzmir 1996 (Atalay).

-ATALAY, Oğuz : Medeni Usul Hukukunda Menfi Vakıaların İspatı, İzmir 2001 (Atalay- Menfi Vakıa).

-ATALAY, Oğuz : Borca Batıklık ve İflâsın Ertelenmesi, İzmir 2006 (Atalay-İflâsın Ertelenmesi).

\footnotetext{
* Kaynakçada kısaltılmış şekilleri ayrıca gösterilmeyen eserler, metinde, yazarların soyadı ile belirtilmiştir. Aynı yazarın birden fazla eserine yollama yapılmışsa, kullanılan kısaltmalar, ilgili kaynağın yanında parantez içinde ayrıca gösterilmiştir.
} 
-AYITER, Kudret : Medeni Hukukta Tasarruf Muameleleri, Ankara 1953.

•BELGESAY, Mustafa Reşit : İcra ve İflâs Kanunu Şerhi, İkinci Bölüm, İstanbul 1950.

•BERKİN, Necmeddin : İflâs Hukuku, 4.B., İstanbul 1972 .

-BERZ, Hans Peter: Der Paulianische Rückerstattungsanspruch, Zürich 1960.

•BOZER, Ali : Borçlar Hukuku Genel Hükümler, Ankara 2002.

- BRÜGGER, Erwin: SchKG Gerichtspraxis 1946-2005, Zürich 2006.

•BREUER, Wolfgang, Insolvenzrecht, 2.Aufl., München 2003.

- EREN, Fikret : Borçlar Hukuku Genel Hükümler, 9.B., Ankara 2006.

•ERTEKİN,Erol/KARATAŞ, İzzet: İstihkak ve Tasarrufun İptali Davaları, Ankara 1995.

-ESENER,Turhan: Türk Hususi Hukukunda Muvazaalı Muameleler, Ankara 1956.

-GAUGLER, Hans: Die Paulianische Anfechtung Band- I, Basel 1944.

-GÜNEREN, Ali : İcra ve İflâs Hukukunda İstihkak Davaları ile Tasarruf İptal Davaları, Ankara 2004.

•GÜRDOĞAN, Burhan: İptal Davaları (İcra ve İflâs Kanunu Değişiklik Tasarıs1 Hakkında Seminere Sunulan Bildiri, Ankara 1963, s. 157168 (Gürdoğan-Seminer).

-GÜRDOĞAN, Burhan : İflâs Hukuku Dersleri (İflâs/Konkordato/İptal Davaları), Ankara 1966 (Gürdoğan-İflas Hukuku).

•HÄSEMEYER, Ludwig : Insolvenzrecht, 4.Aufl., Köln-München 2007.

-JAEGER,Carl :Bundesgesetz über Schuldbetreibung und Konkurs, 4.Aufl., Zürich 2001.

•KAÇAK,Nazif: Tasarruf İptal Davaları, Ankara 2006 (Kaçak). 
•KAÇAK,Nazif: İcra ve İflâs Kanunu Şerhi, C.II, 3.B, Ankara 2006 (Kaçak-Şerh).

-KALE, Serdar: Aciz Hâlindeki Borçlunun Bir veya Birkaç Alacaklısını Kayıran Hukuki Fiilleri Dolayısıyla İptal Davası: Prof Dr. Ergun Önen'e Armağan, İstanbul 2003, s. 191-204.

-KARATAŞ, İzzet/ ERTEKİN, Erol: Tasarrufun İptali Davaları, 1998.

•KILIÇOĞLU, Ahmet : Borçlar Hukuku Genel Hükümler, 7.B., Ankara 2006.

-KIRCHOF, Hans-Peter /LWOWSKI,Jürgen/STÜRNER,Rolf: Münchener Kommentar zur Insolvenzordnung Band 2 ( $\S 203-269)$, München 2002.

-KONURALP, Halûk: Medeni Usul Hukukunda İspat Kurallarının Zorlanan Sinırları, Ankara 1999.

•KORKUSUZ, Refik: İcra ve İflâs Hukuku Uygulaması, Ankara 2004.

•KOSTAKOĞLU, Cengiz : Türk Hukukunda İptal Davaları, AD 1989/6, s. 7-33.

•KUNTER,Nurullah/YENİSEY,Feridun/NUHOĞLU, Muhakeme Hukuku Dalı Olarak Ceza Muhakemesi Hukuku, İstanbul 2006.

•KURTOĞLU, Serda: İcra Hukuku Açısından İptal Davasının Hukuki Niteliği, İBD 1973/7-8, s. 776-780.

•KURU, Baki: İcra ve İflâs Hukuku C. IV, 3.B., İstanbul 1997 (Kuruİcra IV).

•KURU, Baki: İcra ve İflâs Hukuku El Kitabı, 2. Tıpkı B., Ankara 2006 (Kuru-El Kitabi).

•KURU,Baki/ARSLAN, Ramazan/YILMAZ, Ejder : İcra ve İflâs Hukuku Ders Kitab1, 22.Bask1, Ankara 2008 (Kuru/Arslan/Y1lmazİcra).

•MUŞUL,Timuçin: İcra ve İflâs Hukuku, İstanbul 2005. 
-OĞUZMAN,M. Kemal/ ÖZ, Turgut: Borçlar Hukuku Genel Hükümler, 4.B., İstanbul 2005.

-OLGAÇ, Senai : Yargıtay İçtihatlarının Işığı Altında İcra ve İflâs Hukukunda İptal Davaları, Recai Seçkin'e Armağan, Ankara 1974, s. $457-480$.

•ÖNEN, Turgut: Borçlar Hukuku, Genel Hükümler, Ankara 1999.

•ÖZDÍL, Zekai: Tasarrufun İptalini Gerektiren Hukuksal Nedenler, İzBD 1984/4, s. 29-36.

-ÖZKAYA, Eraslan: İnançlı İşlem ve Muvazaa Davaları, 3.B., Ankara 2004 (Özkaya-Muvazaa Davası).

•ÖZMEN,İhsan/ ÖZKAYA, Eraslan: Muvazaa Davaları, Ankara 1993.

-ÖZTEK,Selçuk : İcra ve İflâs Hukukunda Borç Ödemeden Aciz Vesikası, İstanbul 1994 (Öztek-Aciz Belgesi).

•ÖZTEK,Selçuk : Tasarrufun İptali Davalarında Ortaya Çıkan Bazı Sorunlar ve Yargıtay'ın Bu Sorunlara İlişkin Uygulamaları, Prof. Dr. Ergun Önen'e Armağan, İstanbul 2003, s. 319-332 (Öztek).

•PEKCANITEZ, Hakan /ATALAY, Oğuz / SUNGURTEKİNÖZKAN, Meral /ÖZEKES, Muhammet : İcra ve İflâs Hukuku, 4.B., Ankara 2006 (Pekcanıtez/Atalay/Sungurtekin-Özkan/Özekesİcra).

-PEKCANITEZ, Hakan /ATALAY, Oğuz /ÖZEKES, Muhammet: Medenî Usûl Hukuku, 6.B., Ankara 2007.

-POSTACIĞLU, E.İlhan : Namı Müstear Meselesi-Vekâlet ve İtimat Mukaveleleri ile Muvazaanın Karşılıklı Münasebetleri, C. XIII, İHFM 1947/3, s. 1027-1032.

-STAEHELIN, Adrian / BAUER, Thomas : Kommentar zum Bundesgesetz Über Schuldbetreibung und Konkurs (SchKG III- Art 221-352), Basel/Genf/München 1998 (Staehelin/Bauer).

•SÜPHANDAĞ, Yavuz : İcra ve İflâs Hukukunda Uygulamalar, 3.B.,Ankara 2006. 
-TAŞPINAR AYVAZ, Sema : İcra ve İflâs Hukukunda Yeniden Yapılandirma, Ankara 2005.

-TUHR, von Andreas (çev: Cevat Edege) : Borçlar Hukukunun Umumi Kısm1, C.I, İstanbul 1952.

•TUNÇOMAĞ, Kenan: Borçlar Hukuku, Genel Hükümler, C.I, 4.B., İstanbul 1969.

-TÜRK, Ahmet : Anonim Ortaklıkta Sermaye Kayb1 ve Borca Batıklığın Hukuki Sonuçları, Ankara 1999.

-UHLENBERG, Wilhelm :Insolvenzordnung Kommentar, 12.Aufl., München 2003.

•ULUKAPI, Ömer : İcra ve İflâs Hukuku, Konya 2001.

-UMAR,Bilge : Türk İcra ve İflâs Hukukunda İptal Davaları, İstanbul 1963 (Umar-İptal davas1).

-UMAR,Bilge : Aciz Hâli- Borca Batıklık Kavramlarının Farkı ve Bu Yönden Yeni MK. Metninin Düştüğü Bir Yanlışlık (MK m. 605f.II, 618), YÜHFD 2004/1 s. 319-327 (Umar- Borca Batıklık).

-UMAR,Bilge/YILMAZ, Ejder : İsbat Yükü, 2.B.,İstanbul 1980 (Umar/Yilmaz).

-UYAR, Talih : İcra ve İflâs Hukukunda İptal Davaları, 2.B., Ankara 1992 (Uyar-İptal Davasi).

-UYAR, Talih: İcra ve İflâs Hukukunda "Alacaklilara Zarar Vermek Kasdı İle Yapılan Hileli Tasarruflardan Dolayı İptal”(İIY m.280), MBD Nisan 1992/41, s.14-23 (Uyar- Zarar Verme).

•UYAR, Talih: İcra ve İflâs Kanunu, İIK 277-355, C.VI, İzmir 1999 (Uyar-Şerh).

ÜLKÜ,Murat Fatih: Muvazaa Davaları İle İptal Davası Arasındaki İlişki, MBD 1997/62-63 , s.81-89.

•ÜSTÜNDAĞ, Saim : İflâs Hukuku (İflâs, Konkordato, İptal Davaları), 5.B., İstanbul 1998 (İflas Hukuku). 
•ÜSTÜNDAĞ, Saim : Medeni Yargılama Hukuku, 7.B., İstanbul 2000 (Üstündağ-Yargılama).

-YAVUZ, Nihat : Alacaklılardan Mal Kaçırmaya Yönelik İşlemlerin Hukuken Nitelendirilmesi Sorunu ve Bu Amaçla Yapılan Muvazaalı İşlemler Hakkındaki Yargıtay Uygulamasından Örnekler, YD 1999/3, s. 217-241.

-YILDIRIM, M. Kamil : Medeni Usul Hukukunda Delillerin Değerlendirilmesi, İstanbul $1990 \quad$ (Y1ldırım-Delillerin Değerlendirilmesi).

•YILDIRIM, M. Kamil : İcra ve İflâs Hukukunda İptal Davaları, İstanbul 1995 (Yıldırım-İptal Davas1).

-WALDER, Hans Ulrich : Schuldbetreibungs und Konkurs (SchKG), 17 . Aufl., Zürich 2007.

www.kazanc1.com.

www.hukukturk.com.

http://www.gesetze-im-internet.de/aktuell.html. 
